Supporting Information for:

\title{
Luminescent Covalent Organic Frameworks Containing a Homogenous and Heterogeneous Distribution of Dehydrobenzoannulene Vertex Units
}

JONATHAN W. CROWE, LUKE A. BALDWIN, PSARAS L. MCGRIER*

Department of Chemistry \& Biochemistry, The Ohio State University, Columbus, Ohio 43210

Table of Contents

\begin{tabular}{|c|c|c|}
\hline A. & Materials & S2 \\
\hline B. & Instrumentation and Methods & S2 \\
\hline C. & Synthetic Methods & S3 \\
\hline D. & FT-IR Spectra & S6 \\
\hline E. & $\begin{array}{c}\text { Experimental \& Simulated } \\
\text { PXRD Patterns }\end{array}$ & S9 \\
\hline F. & TGA Analysis & S15 \\
\hline G. & Surface Area Analysis & S17 \\
\hline H. & Solid State ${ }^{13}$ C NMR Spectra & S20 \\
\hline I. & SEM Images & S22 \\
\hline J. & UV-Vis and Fluorescence & S23 \\
\hline K. & $\begin{array}{c}\text { DBA-COF Hydrolysis }{ }^{1} \mathrm{H} \text { NMR } \\
\text { Spectra }\end{array}$ & $\mathrm{S} 27$ \\
\hline
\end{tabular}




\section{A. Materials}

Unless stated otherwise all reagents were purchased from commercial sources and used without further purification. 1,4-Dioxane and mesitylene were distilled over $\mathrm{CaH}_{2}$; 3-pentanone was distilled over $\mathrm{MgSO}_{4}$. Tetrahydrofuran (THF) was purified by passage over activated alumina. Pyrene-2,7-diboronic acid (PDBA) was prepared according to reported method. ${ }^{[1]}$ Prep TLC purifications were performed using $1500 \mu \mathrm{m}$ plates from Analtech without fluorescent indicator.

\section{B. Instrumentation and Methods}

Infrared spectra were recorded on a Thermo Scientific Nicolet iS5 with an iD7 diamond ATR attachment and are uncorrected.

UV-vis absorbance spectra were recorded on a Cary 5000 UV-vis/NIR spectrophotometer using an internal DRA with stock powder cell holder to record the \% reflectance spectra. Emission spectra were recorded on a Cary Eclipse Fluorescence spectrophotometer equipped with a xenon flash lamp.

X-ray diffraction patters were recorded on a Bruker D8 Powder X-Ray Diffractometer employing $\mathrm{Cu} \mathrm{K}(\alpha)^{1}$ line focused irradiation at $40 \mathrm{kV}, 50 \mathrm{~mA}$ power and equipped with a $\mathrm{Ge}$ (111) monochromator. Samples were mounted on a zero background sample holder by dropping powders from a vial and then flattening them by firmly pressing the sample with a wide-blade spatula. No sample grinding was used prior to analysis. The holder was then placed on the mounting apparatus in the diffractometer. Data was collected after a 12 minute delay time using a $0.015^{\circ} 2 \theta$ step scan from $1-34^{\circ}$ with an exposure timer of 2-3 sec per step.

Thermogravimetric analyses (TGA) were carried using a Perkin-Elmer thermal gravimetric analyzer 7 by heating samples in a platinum pan from $35^{\circ} \mathrm{C}$ to $1000{ }^{\circ} \mathrm{C}$ under nitrogen atmosphere at a heating rate of $10{ }^{\circ} \mathrm{C} \mathrm{min}{ }^{-1}$ without an equilibration delay.

Scanning electron microscopy (SEM) was performed on a FEI Sirion FE-SEM. Materials were deposited thinly, by gently scrapping them over the surface of a carbon sticky tab attached to an aluminum sample stub. The samples were coated with gold in a Leica EM ACE600 coater, using rotation, to a depth of approximately $20 \mathrm{~nm}$. After coating the samples were imaged in the SEM at $5 \mathrm{keV}$, without tilting, using both the secondary electron (SE) detector and the through lens detector (TLD).

Surface area measurements were conducted on a Micromeritics ASAP 2020 Surface Area and Porosity Analyzer using ca. $20 \mathrm{mg}$ samples. Nitrogen isotherms were generated by incremental exposure to ultra high purity nitrogen up to ca. 1 atm in a liquid nitrogen $(77 \mathrm{~K})$ bath. Surface parameters were determined using BET adsorption models in the instrument software. Pore size distributions were determined using non-local density functional theory (NLDFT) model (cylinder pore, $\mathrm{N}_{2}$-cyclindrical pores-oxide surface with high regularization) in the instrument software (Micromeritics ASAP 2020 V4. 02). 
${ }^{1} \mathrm{H}-\mathrm{NMR}$ spectra were recorded in deuterated solvents on a Bruker Avance DPX $400(400 \mathrm{MHz})$. Chemical shifts are reported in parts per million $(\mathrm{ppm}, \delta)$ using the solvent as internal standard. ${ }^{13} \mathrm{C}-\mathrm{NMR}$ spectra were recorded on a Bruker Avance DPX $400(100 \mathrm{MHz})$ and Bruker Avance III $\mathrm{HD}$ Ascend $600(150 \mathrm{MHz})$ using the solvent as an internal standard.

High-resolution solid-state NMR spectra were obtained at room temperature utilizing a Bruker DPX spectrometer operating at $300.13 \mathrm{MHz}$ and $75.5 \mathrm{MHz}$ for proton $\left({ }^{1} \mathrm{H}\right)$ and carbon $\left({ }^{13} \mathrm{C}\right)$, respectively. The ${ }^{13} \mathrm{C}$ chemical shifts are reported with respect to adamantane (29.5 ppm) relative to the TMS at $0.00 \mathrm{ppm}$. The ${ }^{13} \mathrm{C}$ CP-MAS NMR spectra were collected using a twochannel probe in $4 \mathrm{~mm}$ rotors spinning at $10 \mathrm{kHz}$. Data were collected by the routine cross polarization (CP-MAS) pulse sequence with a $2 \mathrm{~ms}$ contact time. The proton decoupling field strength was constant at $100 \mathrm{kHz}$ during the acquisition of the spectra, the relaxation delay was $2 \mathrm{sec}$, and 32k transients were collected. Data processing included $20 \mathrm{~Hz}$ line broadening.

Elemental analysis was performed by Galbraith Laboratories.

\section{Synthetic Methods}

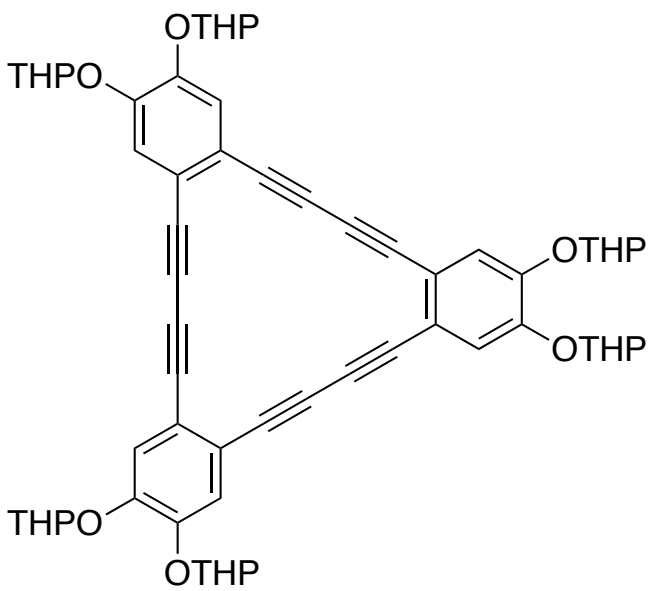

DBA[18]-OTHP

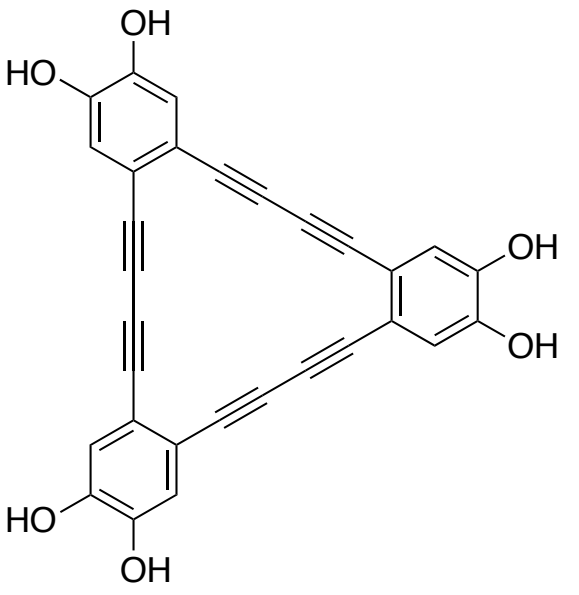

DBA[18]-OH

DBA[18]-OTHP: This compound was prepared using a procedure from Baldwin et al. ${ }^{[2]}$

DBA[18]-OH: This compound was prepared in modified procedure from Baldwin et al. ${ }^{[2]}$ To a solution of DBA[18]-OTHP (600 mg, $0.617 \mathrm{mmol}, 1$ equiv) in THF (40 mL, 0.015M) was added $\mathrm{HCl}\left(1 \mathrm{M}, 6.2 \mathrm{~mL}, 10\right.$ equiv) and the resulting mixture was stirred for 18 hours at $23^{\circ} \mathrm{C}$. The reaction mixture was concentrated to remove nearly all the solvent; the resultant mixture is a yellow slurry. The slurry is filtered and rinsed with $\mathrm{H}_{2} \mathrm{O}(100 \mathrm{~mL}), \mathrm{CH}_{2} \mathrm{Cl}_{2}(100 \mathrm{~mL})$ and hexanes $(100 \mathrm{~mL})$. The resulting yellow solid was stirred in $\mathrm{CH}_{2} \mathrm{Cl}_{2}(40 \mathrm{~mL})$ for 5 hours to remove excess $\mathrm{H}$-bonded THF and then filtered to afford the title compound DBA[18]-OH (270 mg, $0.576 \mathrm{mmol}$, $93 \%$ yield) as a yellow-brown solid. ${ }^{1} \mathrm{H}-\mathrm{NMR}\left(\mathrm{DMSO}-d_{6}, 400 \mathrm{MHz}\right) \delta 10.16(\mathrm{~s}, 6 \mathrm{H}), 7.09(\mathrm{~s}, 6 \mathrm{H})$. ${ }^{13} \mathrm{C}-\mathrm{NMR}\left(\mathrm{DMSO}-d_{6}, 100 \mathrm{MHz}\right) \delta 147.7,118.8,115.5,81.0,75.6 \mathrm{HRMS}$ (ESI) $\mathrm{m} / \mathrm{z}$ calculated for $\mathrm{C}_{30} \mathrm{H}_{12} \mathrm{O}_{6}(\mathrm{M}-\mathrm{H})^{-}:$467.0550, found: 467.0566. FT-IR (powder, ATR) 3157, 2207, 2139, 1594, $1573,1503,1450,1350,1294,1253,1135 \mathrm{~cm}^{-1}$. 
DBA[12]-OH: This compound was prepared using a procedure from Baldwin et al. ${ }^{[2]}$

\section{Synthetic Procedures for DBA-PDBA COFs}

General Solvothermal COF Conditions: DBA and diboronic acid monomers were combined in a $10.6 \mathrm{~cm} \times 1.8 \mathrm{~cm}(\mathrm{~L} \times \mathrm{W}), 10 \mathrm{~mL}$ prescored ampule (Sigma-Z184985). Solvent was then added and the suspension was sonicated for 1 minute before freezing in a liquid nitrogen bath. The solution was then degassed using standard freeze-pump-thaw procedures and sealed under vacuum ( 150 mTorr), which subsequently reduces the ampule to $8.5 \mathrm{~cm}$ (L) upon sealing, and placed in the oven for the allotted time. After the reaction is complete the COFs were allowed to cool to room temperature and transferred into $20 \mathrm{~mL}$ scintillation vials with THF $(15 \mathrm{~mL})$. The supernatant liquid was changed out 3 times over 36 hours. THF was chosen because DBA[18]-OH is most soluble compared to MeCN. After final removal of supernatant THF the solids were placed on high vacuum for 4 hours to remove most of the residual solvent before being activated on the ASAP 2020 for further analysis.

Py-DBA-COF 1: A mixture of DBA[12]-OH (20.0 mg, $0.05 \mathrm{mmol}, 1$ equiv.) and PDBA (21.8 mg, $0.075 \mathrm{mmol}, 1.5$ equiv.) in 1,4-dioxane/ mesitylene $(2: 1,1.0 \mathrm{~mL}, 0.05 \mathrm{M})$ was sonicated in a 10 $\mathrm{mL}$ prescored glass ampule for 1 minute. The suspension was then degassed via 3 freezepump-thaw cycles at $77 \mathrm{~K}$ before sealing under vacuum. After warming to room temperature the ampule was placed in a gravity convection oven at $105^{\circ} \mathrm{C}$ for 72 hours. After the allotted time the ampule was allowed to cool to room temperature and then transferred to a $20 \mathrm{~mL}$ scintillation vial with $\mathrm{MeCN}$. The solvent was decanted and exchanged with MeCN (3x with 15 $\mathrm{mL}$ ) over 36 hours. After decanting the solvent, the solid was dried under vacuum, to give a yellow-brown solid (19 mg, 52\% yield). FT-IR (powder, ATR) 3522, 1609, 1506, 1464, 1424, 1374, 1335, 1230, 1187, 1106, 999, 902, 863, 795, 781, 713, $670 \mathrm{~cm}^{-1}$. Elemental Analysis for $\left(\mathrm{C}_{48} \mathrm{H}_{18} \mathrm{~B}_{3} \mathrm{O}_{6}\right)_{\mathrm{n}}$ : Calculated: $\mathrm{C}(79.7 \%), \mathrm{H}(2.5 \%)$; Observed: $\mathrm{C}(70.6 \%), \mathrm{H}(2.74 \%)$. The observed carbon values are lower than the calculated on account of the formation of non-combustible boron carbide byproducts and has been observed for other boronate ester linked COFs. ${ }^{3,4}$

${ }^{*}$ No screening was conducted for Py-DBA-COF 1 as the initial reaction conditions described above gave a highly porous, crystalline material on the first attempt.

Py-DBA-COF 2: A mixture of DBA[18]-OH (19.4 mg, $0.041 \mathrm{mmol}, 1$ equiv.) and PDBA (23.2 mg, $0.080 \mathrm{mmol}, 2$ equiv.) in 3-pentanone/ mesitylene $(2: 1,1.2 \mathrm{~mL}, 0.034 \mathrm{M})$ was sonicated in a 10 $\mathrm{mL}$ prescored glass ampule for 1 minute. The suspension was then degassed via 3 freezepump-thaw cycles at $77 \mathrm{~K}$ before sealing under vacuum. After warming to room temperature the ampule was placed in gravity convection oven at $105{ }^{\circ} \mathrm{C}$ for 72 hours. After the allotted time the ampule was allowed to cool to room temperature and then transferred with THF to a $20 \mathrm{~mL}$ scintillation vial. The solvent was decanted and exchanged with THF (3x with $15 \mathrm{~mL}$ ) over 36 hours at which point the solid was dried under high vacuum, to give a brown solid $(28 \mathrm{mg}, 85 \%$ yield). FT-IR (powder, ATR) 1773, 1697, 1607, 1577, 1501, 1460, 1329, 1250, 1227, 1201, $1140,1105,977,889,866,796,713,670 \mathrm{~cm}^{-1}$. Elemental Analysis for $\left(\mathrm{C}_{54} \mathrm{H}_{18} \mathrm{~B}_{3} \mathrm{O}_{6}\right)_{\mathrm{n}}$ : Calculated: C (81.6\%), H (2.3\%); Observed: C (74.5\%), H (3.1\%). The observed carbon values are lower than the calculated on account of the formation of non-combustible boron carbide byproducts and has been observed for other boronate ester linked COFs. ${ }^{3,4}$ 
Table S1. Screening conditions for Py-DBA-COF 2:

\begin{tabular}{|c|c|c|c|c|}
\hline $\begin{array}{c}\text { Equiv. } \\
\text { DBA[18]-OH }\end{array}$ & $\begin{array}{c}\text { Equiv. } \\
\text { PDBA }\end{array}$ & Solvent/ molarity & Temp $\left.{ }^{\circ} \mathbf{C}\right)$ & Result \\
\hline 1 & 1.5 & 2:1 Dioxane: Mesitylene (0.01M) & 105 & non porous \\
\hline 1 & 1.5 & 3:1 Dioxane: Mesitylene (0.04M) & 105 & $400 \mathrm{~m}^{2} \mathrm{~g}^{-1}$ \\
\hline 1 & 1.5 & 3:1 Dioxane: Mesitylene $(0.05 \mathrm{M})$ & 120 & $570 \mathrm{~m}^{2} \mathrm{~g}^{-1}$ \\
\hline 1 & 2 & 3:1 Dioxane: Mesitylene (0.05M) & 120 & $660 \mathrm{~m}^{2} \mathrm{~g}^{-1}$ \\
\hline 1 & 2 & 1:1 3-Pentanone: Mesitylene (0.03M) & 105 & $830 \mathrm{~m}^{2} \mathrm{~g}^{-1}$ \\
\hline 1 & 2 & 2:1 3-Pentanone: Mesitylene (0.03M) & 105 & $1354 \mathrm{~m}^{2} \mathrm{~g}^{-1}$ \\
\hline
\end{tabular}

Py-MV-DBA-COF: A mixture of DBA[12] (8.0 mg, $0.02 \mathrm{mmol}, 1$ equiv.), DBA[18] (9.4 mg, 0.02 mmol, 1 equiv.), and PDBA (17 mg, $0.06 \mathrm{mmol}, 3$ equiv.) in 3-pentanone/ mesitylene (2:1, 0.8 $\mathrm{mL}, 0.025 \mathrm{M}$ per DBA) was sonicated in a $10 \mathrm{~mL}$ prescored glass ampule for 1 minute. The suspension was then degassed via 3 freeze-pump-thaw cycles at $77 \mathrm{~K}$ before sealing under vacuum. After warming to room temperature the ampule was placed in a gravity convection oven at $105{ }^{\circ} \mathrm{C}$ for 72 hours. After the allotted time the ampule was allowed to cool to room temperature and then transferred with THF to a $20 \mathrm{~mL}$ scintillation vial and suspended in THF $(15 \mathrm{~mL})$. The THF of the suspension was changed 3 times over 36 hours at which point the solid was dried under high vacuum, to give a green-brown solid (18 $\mathrm{mg}, 60 \%$ yield). FT-IR (powder, ATR) $3045,1701,1608,1577,1502,1463,1424,1331,1228,1186,1144,1105,973,890,865$, 796, $713,671 \mathrm{~cm}^{-1}$. Elemental Analysis for $\left(\mathrm{C}_{51} \mathrm{H}_{18} \mathrm{~B}_{3} \mathrm{O}_{6}\right)_{\mathrm{n}}$ : Calculated: $\mathrm{C}(80.7 \%), \mathrm{H}(2.4 \%)$; Observed: $\mathrm{C}(72.4 \%), \mathrm{H}(3.2 \%)$. The observed carbon values are lower than the calculated on account of the formation of non-combustible boron carbide byproducts and has been observed for other boronate ester linked COFs. ${ }^{3,4}$

Table S2. Screening conditions for Py-MV-DBA-COF:

\begin{tabular}{|c|c|c|c|c|c|}
\hline $\begin{array}{c}\text { Equiv. } \\
\text { DBA[12] }\end{array}$ & $\begin{array}{c}\text { Equiv. } \\
\text { DBA[18] }\end{array}$ & $\begin{array}{c}\text { Equiv. } \\
\text { PDBA }\end{array}$ & Solvent/molarity & $\begin{array}{c}\text { Temperature } \\
\left({ }^{\circ} \mathbf{C}\right)\end{array}$ & Results \\
\hline 1 & 1 & 3 & $3: 1$ Dioxane:Mesitylene (0.05M) & 120 & $208 \mathrm{~m}^{2} \mathrm{~g}^{-1}$ \\
\hline 1 & 1 & 3 & $1: 13$-Pentanone: Mesitylene (0.05M) & 105 & $870 \mathrm{~m}^{2} \mathrm{~g}^{-1}$ \\
\hline 1 & 1 & 3 & $2: 13$ 3-Pentanone: Mesitylene (0.05M) & 105 & $1134 \mathrm{~m}^{2} \mathrm{~g}^{-1}$ \\
\hline
\end{tabular}




\section{FT-IR}

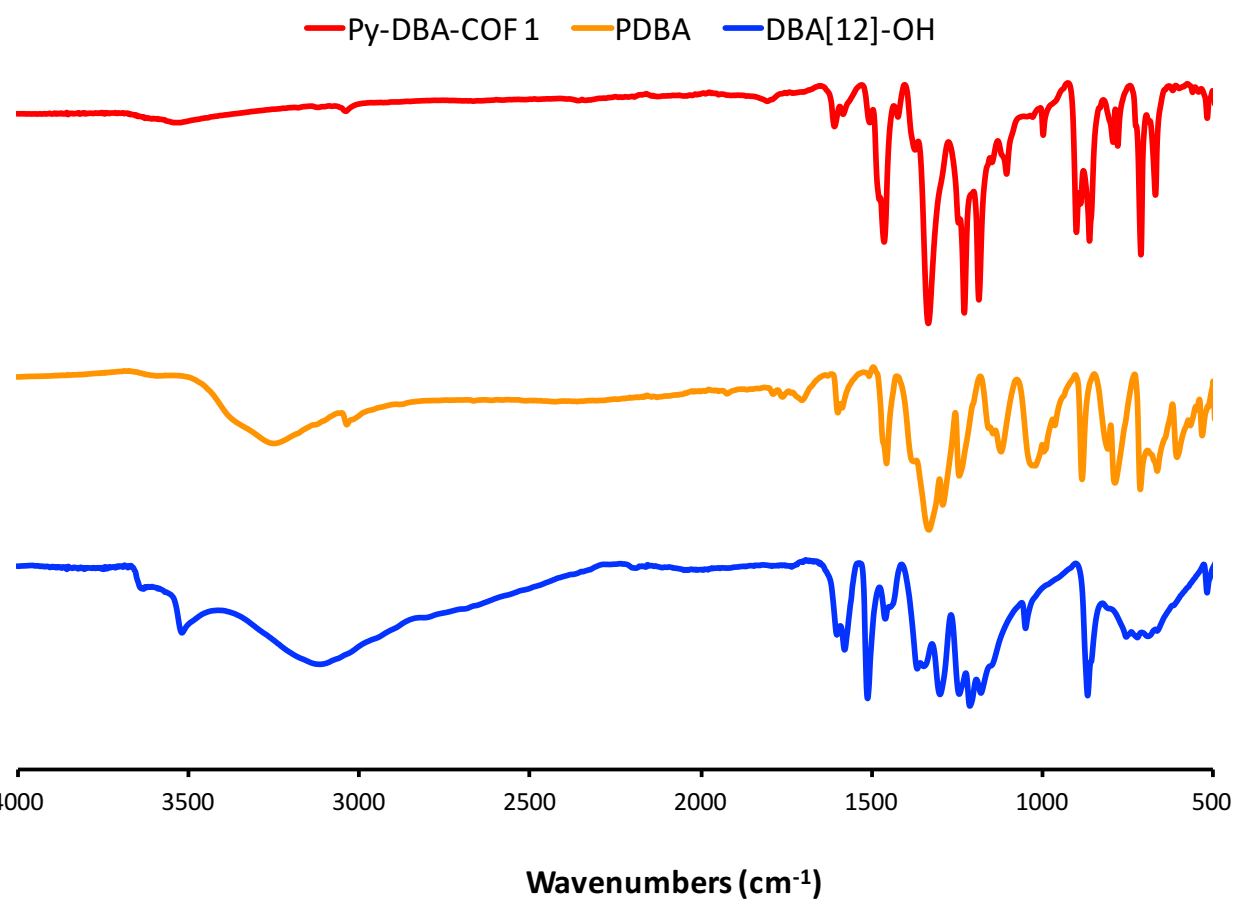

Figure S1. FT-IR of Py-DBA-COF 1, PDBA, and DBA[12]-OH.

Table S3. FT-IR Peak assignment for Py-DBA-COF 1.

\begin{tabular}{|c|c|}
\hline Peak $\mathbf{( c m}^{-\mathbf{1}} \mathbf{)}$ & Assignment \\
\hline 1335 & B-O stretch for boronate ester \\
\hline 1230 & C-O stretch for boronate ester \\
\hline 999 & C-B stretch of boronate ester \\
\hline
\end{tabular}



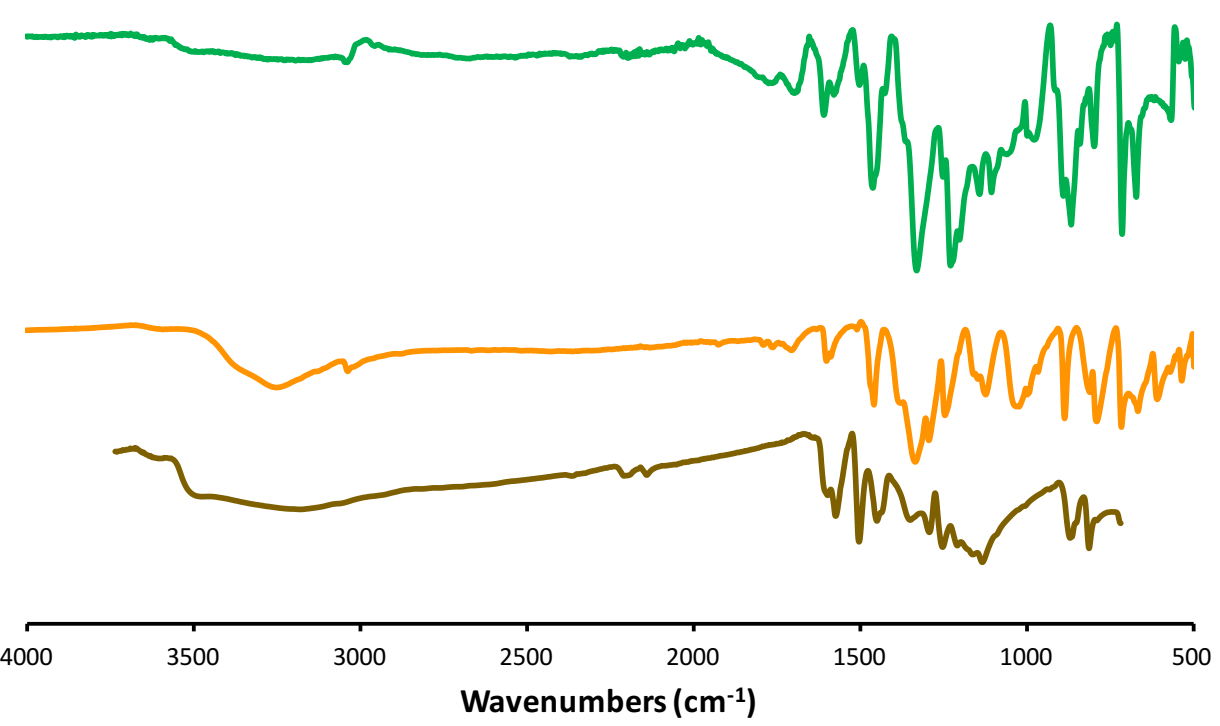

Figure S2. FT-IR of Py-DBA-COF 2, PDBA, and DBA[18]-OH.

Table S4. FT-IR peak assignments for Py-DBA-COF 2.

\begin{tabular}{|c|c|}
\hline Peak $\left.\mathbf{( c m}^{-1}\right)$ & Assignment \\
\hline 1329 & B-O stretch for boronate ester \\
\hline 1227 & C-O stretch for boronate ester \\
\hline 977 & B-C stretch for boronate ester \\
\hline
\end{tabular}



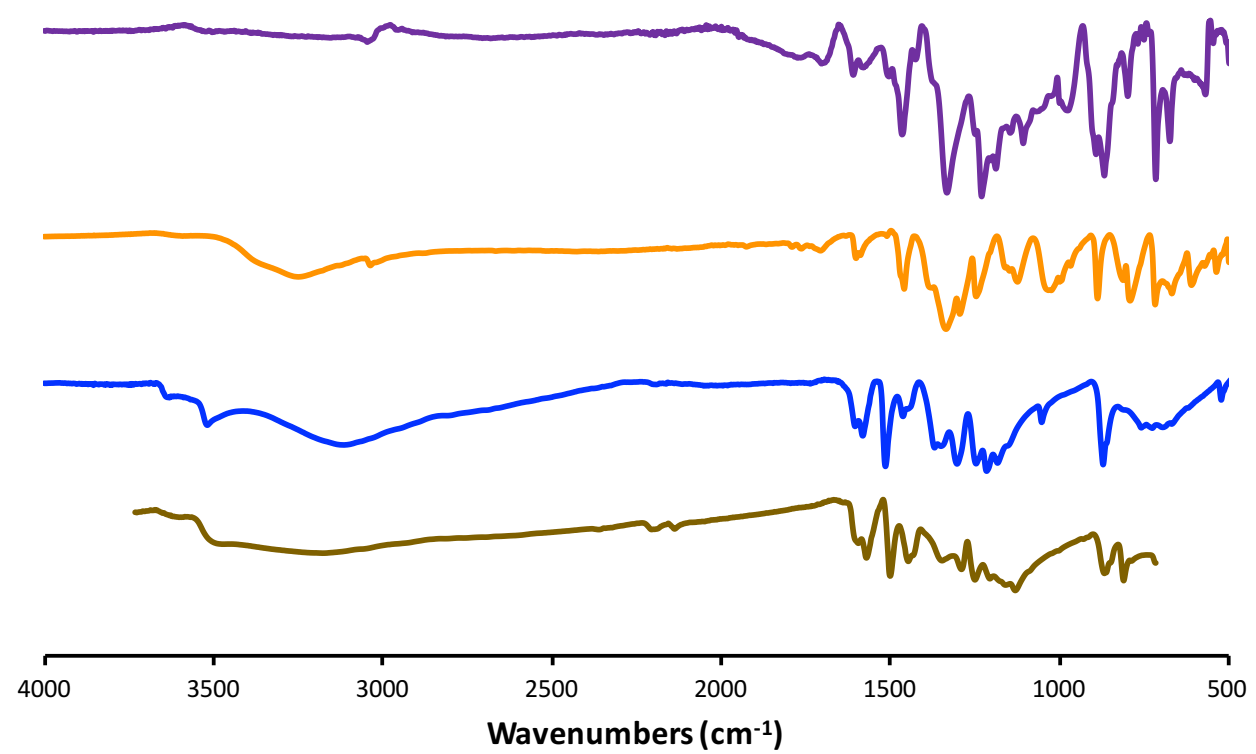

Figure S3. FT-IR of Py-MV-DBA-COF, PDBA, DBA[12]-OH, and DBA[18]-OH.

Table S5. FT-IR Peak assignments for Py-MV-DBA-COF.

\begin{tabular}{|c|c|}
\hline Peak $\left.\mathbf{( c m}^{-1}\right)$ & Assignment \\
\hline 1331 & B-O stretch for boronate ester \\
\hline 1228 & C-O stretch for boronate ester \\
\hline 973 & C-B stretch for boronate ester \\
\hline
\end{tabular}




\section{E. Experimental and Simulated PXRD Profiles}

The simulated PXRD profiles were performed using Materials Studio 7.0 using the unit cell precursors shown in Figure S4. Before the simulations were performed, each precursor was optimized using the geometry optimization task and Universal Forcefield parameters from the Forcite module. Each structure was then modeled using a primitive hexagonal unit cell with a $\mathrm{P} 6 / \mathrm{mmm}$ space group. The $\mathrm{a}=\mathrm{b}$ parameters were estimated by measuring the distance between the phenyl ring of the linkers for each COF. The gra net molecular models were performed by off setting the initial structures by half of the $a=b$ parameters using a gra $\mathrm{P}_{3} / \mathrm{mmc}$ space group and c parameter of $6.7 \AA$. Simulation of the possible structures was performed using Reflux Plus module to produce the expected PXRD profiles. The experimental PXRDs were then subjected to a Pawley refinement using pseudo-Voigt peak shape function and Berar-Baldinozzi asymmetry correction function to produce the refined PXRD profile.

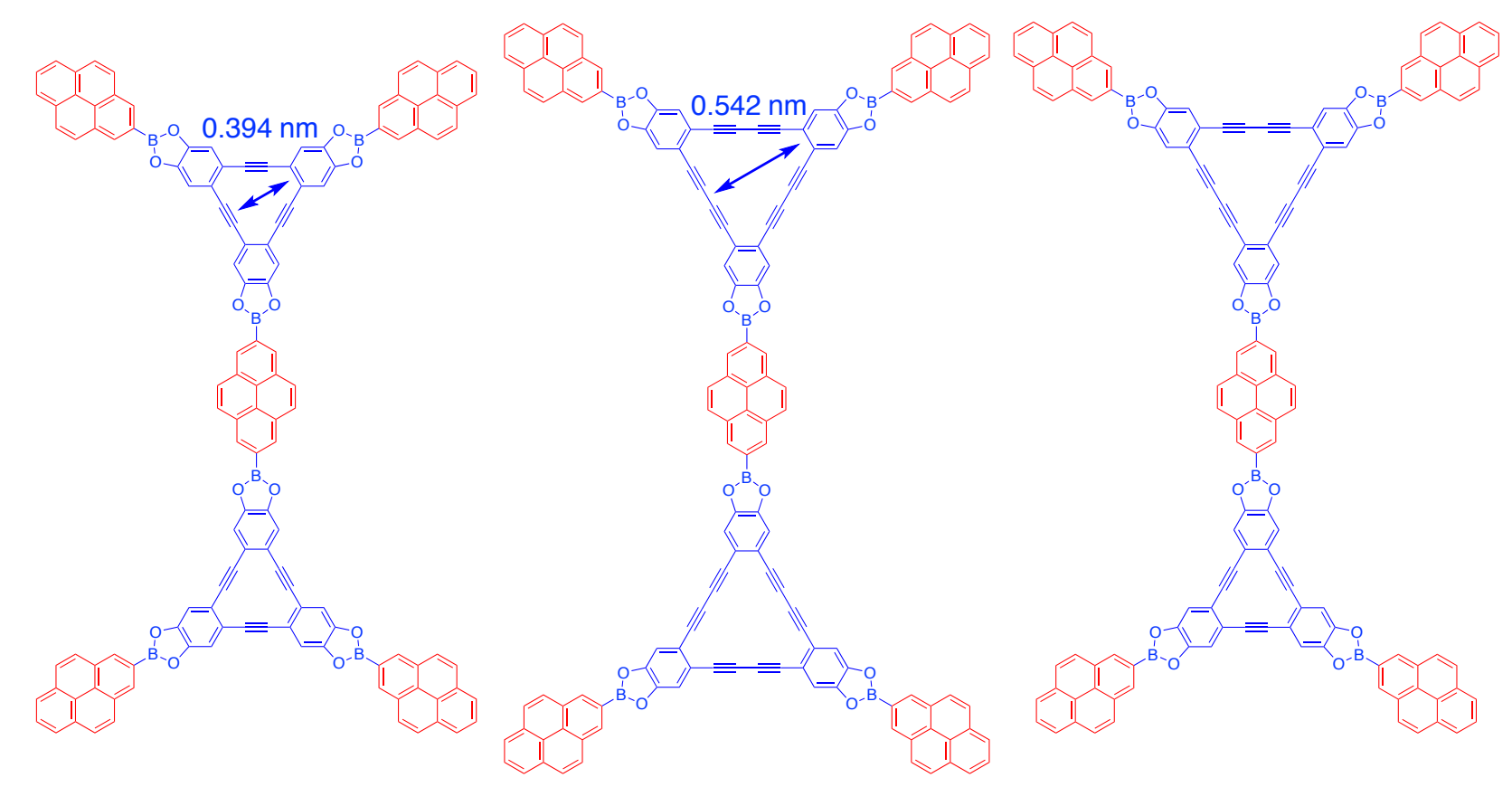

Figure S4. Precursors used to construct the hexagonal unit cells for Py-DBA-COF 1 (left), PyDBA-COF 2 (center), and Py-MV-DBA-COF (right). The triangular pore sizes for the DBA[12] $(0.394 \mathrm{~nm})$ and DBA[18] $(0.542 \mathrm{~nm})$ were estimated by measuring the distance from the phenyl ring and alkyne. 


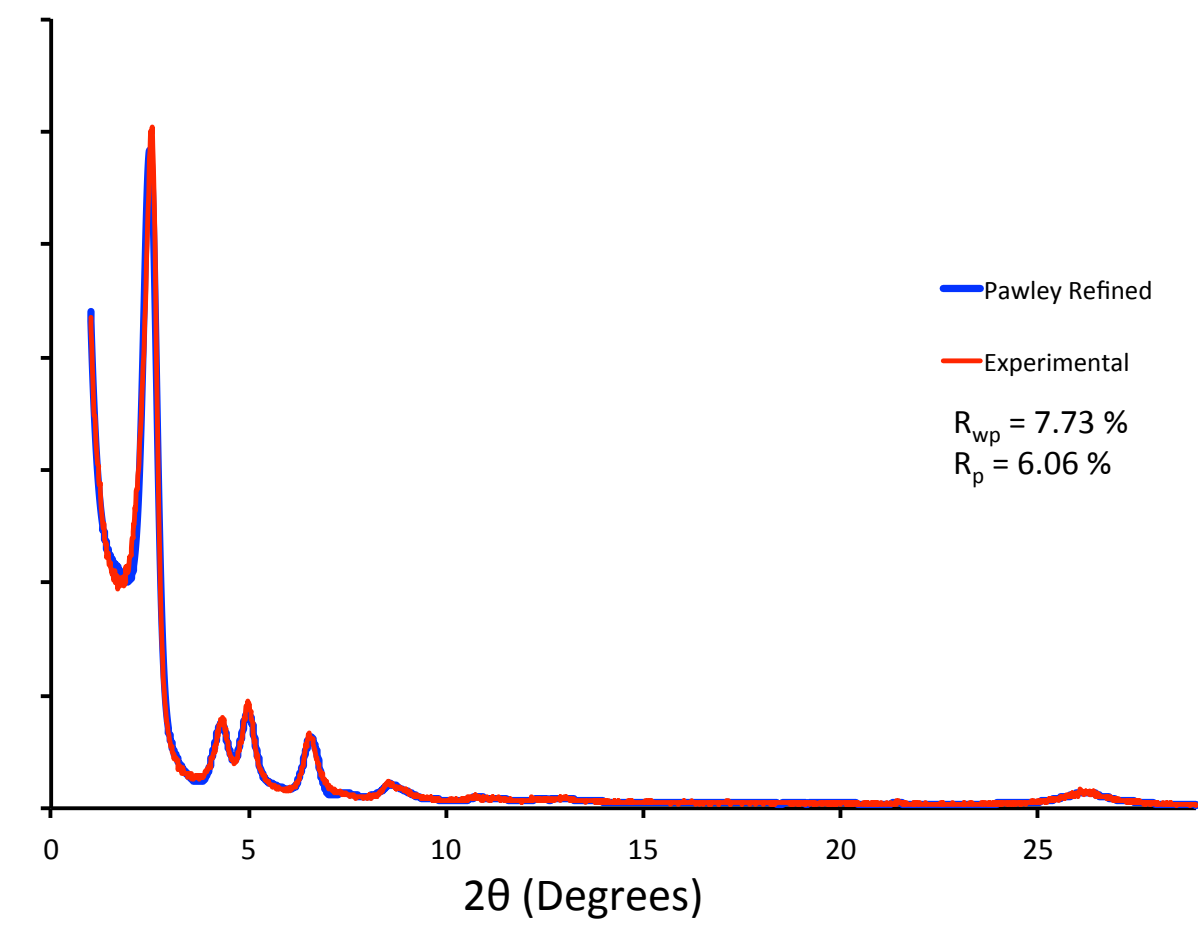

Figure S5. Experimental (red) and Pawley refined (blue) PXRD of Py-DBA-COF 1.

Table S6. Fractional atomic coordinates for the bnn $(\mathrm{P} 6 / \mathrm{mmm})$ unit cell of Py-DBA-COF 1 calculated using Materials Studio 7.0.

\begin{tabular}{|cccc|}
\hline \multicolumn{4}{|c|}{ Py-DBA-COF 1 } \\
\hline \multicolumn{4}{c|}{$\begin{array}{c}\text { Hexagonal, P6/mmm } \\
\mathrm{a}=\mathrm{b}=41.014, \mathrm{c}=3.4\end{array}$} \\
\hline Atom & $\mathbf{X}$ & $\mathbf{Y}$ & $\mathbf{Z}$ \\
$\mathrm{C} 1$ & 0.554734 & 0.486651 & 0.017750 \\
$\mathrm{H} 2$ & 0.587038 & 0.502934 & 0.018085 \\
$\mathrm{C} 3$ & 0.535772 & 0.449141 & 0.019815 \\
$\mathrm{~B} 4$ & 0.556668 & 0.428302 & 0.022570 \\
O5 & 0.596081 & 0.446053 & 0.023149 \\
$\mathrm{C} 6$ & 0.600603 & 0.416445 & 0.025776 \\
$\mathrm{C} 7$ & 0.633520 & 0.417296 & 0.027390 \\
$\mathrm{H} 8$ & 0.661528 & 0.445413 & 0.026546 \\
$\mathrm{C} 9$ & 0.633445 & 0.384711 & 0.030023 \\
$\mathrm{C} 10$ & 0.667456 & 0.385524 & 0.031695 \\
$\mathrm{C} 11$ & 0.695559 & 0.385495 & 0.033133 \\
$\mathrm{C} 12$ & 0.728715 & 0.384613 & 0.034898 \\
$\mathrm{C} 13$ & 0.761478 & 0.417164 & 0.033938 \\
$\mathrm{H} 14$ & 0.762620 & 0.445520 & 0.031702 \\
$\mathrm{C} 15$ & 0.723504 & 0.416246 & 0.035648 \\
\hline
\end{tabular}




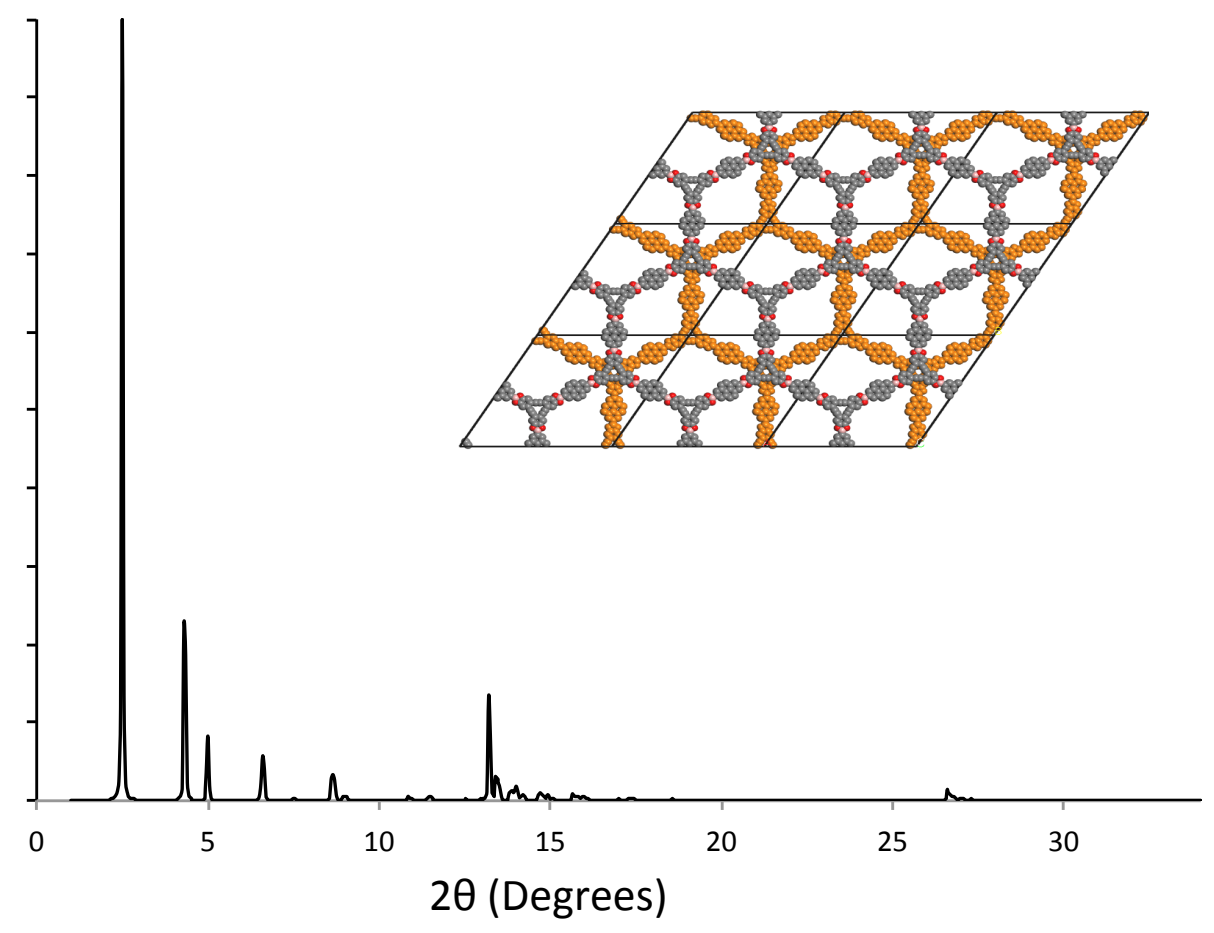

Figure S6. Simulated PXRD of Py-DBA-COF 1 modeled using a gra unit cell (top right).

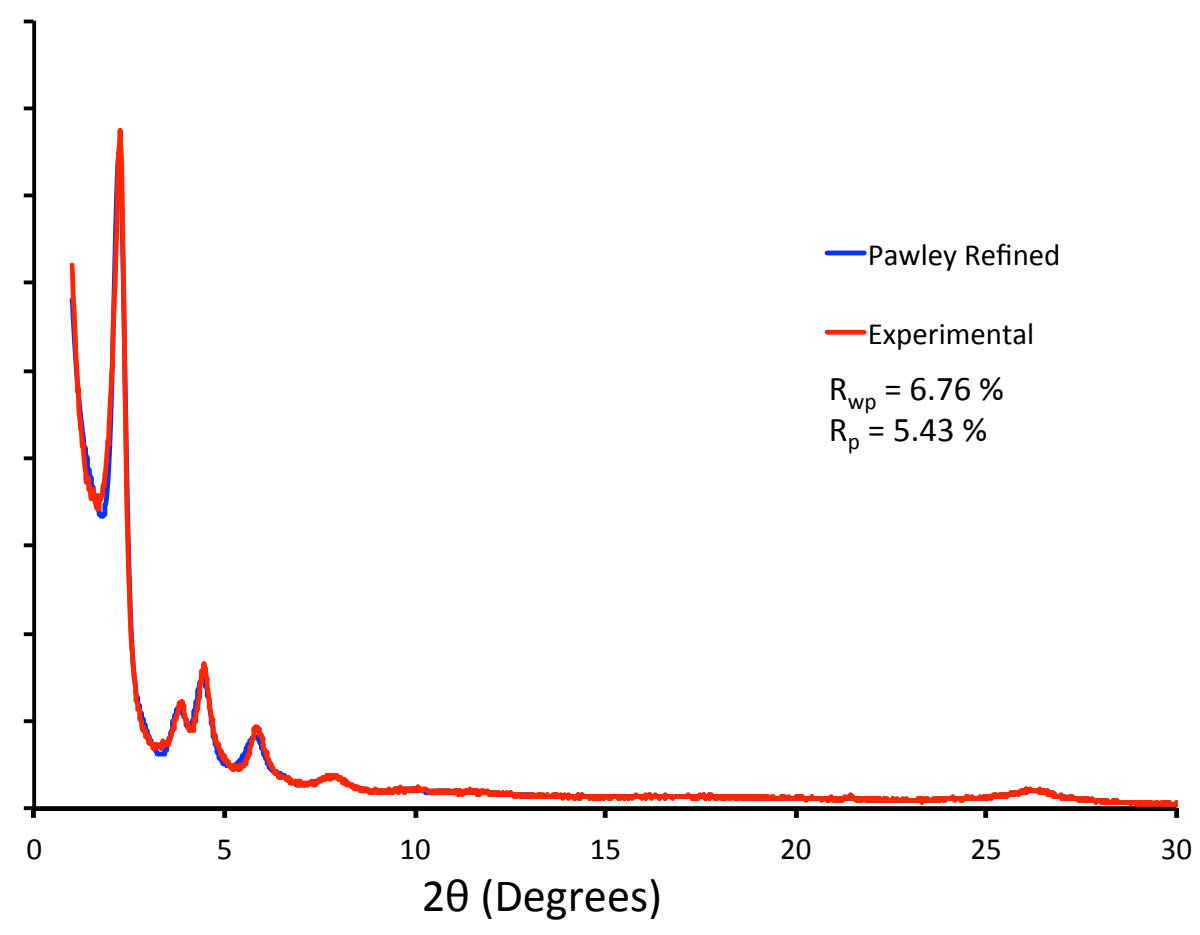

Figure S7. Experimental (red) and Pawley refined (blue) PXRD of Py-DBA-COF 2. 
Table S7. Fractional atomic coordinates for the bnn(P6/mmm) unit cell of Py-DBA-COF 2 calculated using Materials Studio 7.0.

\begin{tabular}{|cccc|}
\hline \multicolumn{4}{|c|}{ Py-DBA-COF 2 } \\
\hline \multicolumn{4}{c|}{ Hexagonal, P6/mmm } \\
& $\mathrm{a}=48.622, \mathrm{~b}=48.834, \mathrm{c}=3.39$ \\
\hline Atom & $\mathbf{X}$ & $\mathbf{Y}$ & $\mathbf{Z}$ \\
C1 & 0.48226 & 0.561882 & 0.046863 \\
H2 & 0.501543 & 0.588837 & 0.046450 \\
C3 & 0.454650 & 0.544898 & 0.047947 \\
B4 & 0.435938 & 0.563512 & 0.048575 \\
O5 & 0.451769 & 0.598714 & 0.048086 \\
C6 & 0.425229 & 0.602699 & 0.048957 \\
C7 & 0.425924 & 0.632073 & 0.048959 \\
H8 & 0.449325 & 0.655462 & 0.048213 \\
C9 & 0.396727 & 0.631961 & 0.049913 \\
C10 & 0.397454 & 0.662347 & 0.049914 \\
C11 & 0.397695 & 0.687581 & 0.049927 \\
C12 & 0.397603 & 0.716933 & 0.049954 \\
C13 & 0.397203 & 0.741843 & 0.049987 \\
C14 & 0.396288 & 0.771401 & 0.050042 \\
C15 & 0.425392 & 0.800702 & 0.049114 \\
\hline
\end{tabular}

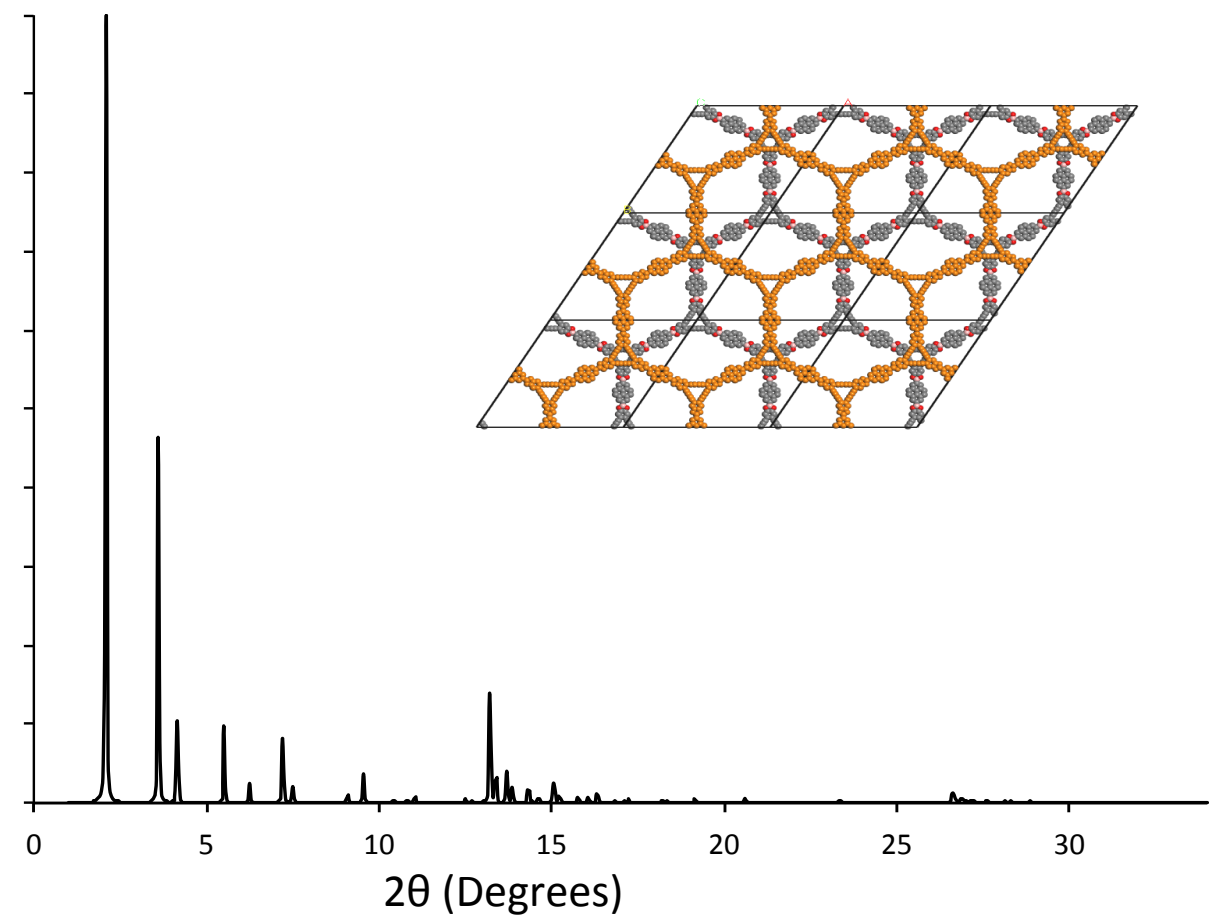

Figure S8. Simulated PXRD of Py-DBA-COF 2 modeled using a gra unit cell (top right). 


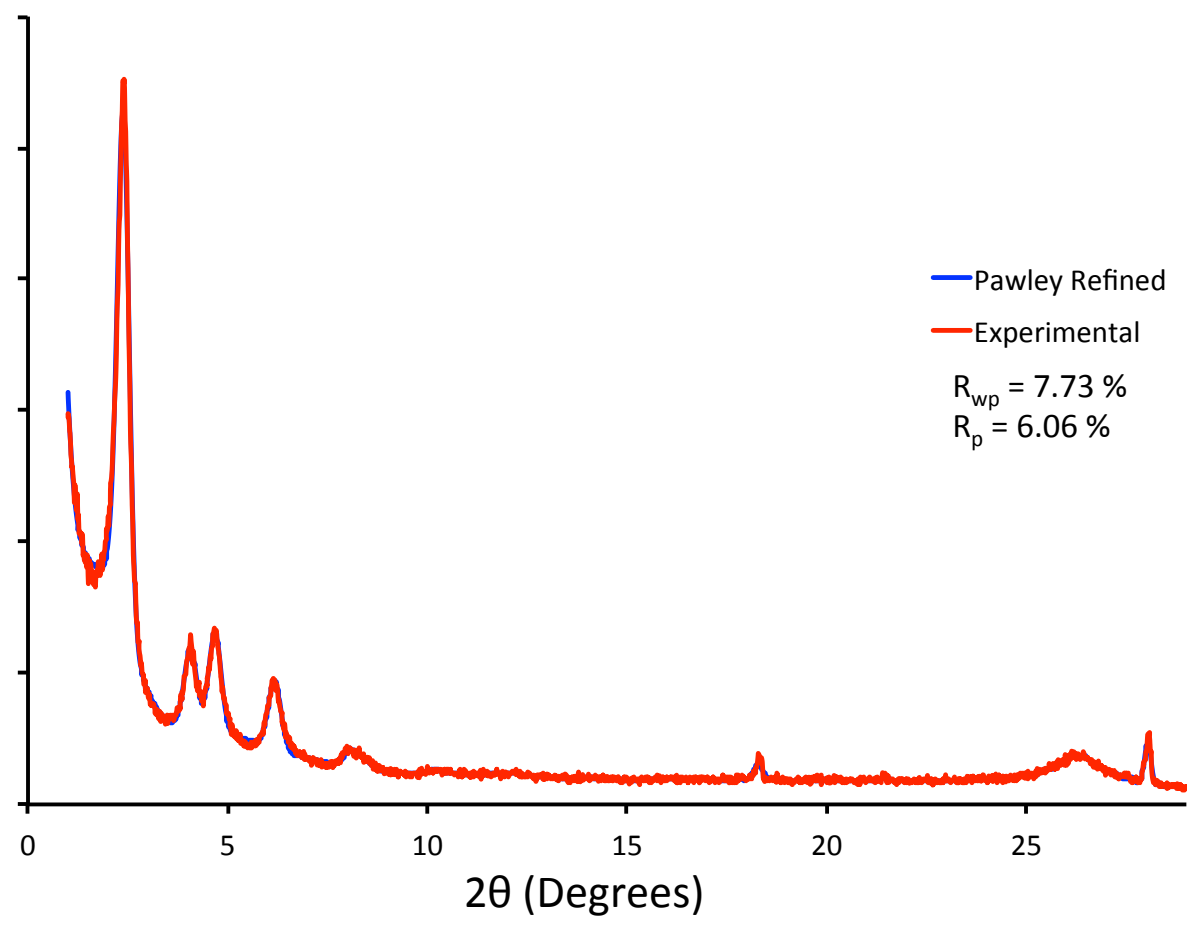

Figure S9. Experimental (red) and Pawley refined (blue) PXRD of Py-MV-DBA-COF.

Table S8. Fractional atomic coordinates for the bnn $(\mathrm{P} 6 / \mathrm{mmm})$ unit cell of Py-MV-DBA COF calculated using Materials Studio 7.0.

\begin{tabular}{|c|c|c|c|}
\hline \multicolumn{4}{|c|}{ Py-MV-DBA-COF } \\
\hline \multicolumn{4}{|c|}{$\begin{array}{c}\text { Hexagonal, P6/mmm } \\
a=43.042, b=43.223, c=3.33\end{array}$} \\
\hline Atom & $\mathbf{X}$ & $\mathbf{Y}$ & $\mathbf{Z}$ \\
\hline $\mathrm{C} 1$ & 0.482844 & 0.465246 & 0.911558 \\
\hline $\mathrm{H} 2$ & 0.467613 & 0.434793 & 0.914390 \\
\hline C3 & 0.518491 & 0.483064 & 0.908362 \\
\hline B4 & 0.538206 & 0.463234 & 0.908499 \\
\hline $\mathrm{O} 5$ & 0.521252 & 0.426010 & 0.911865 \\
\hline C6 & 0.549335 & 0.421642 & 0.910528 \\
\hline C7 & 0.548441 & 0.390513 & 0.912577 \\
\hline H8 & 0.521939 & 0.364156 & 0.915795 \\
\hline C9 & 0.579360 & 0.390472 & 0.910799 \\
\hline C10 & 0.578427 & 0.358271 & 0.912920 \\
\hline C11 & 0.578035 & 0.331527 & 0.914659 \\
\hline C12 & 0.577974 & 0.300417 & 0.916659 \\
\hline C13 & 0.578263 & 0.274013 & 0.918338 \\
\hline C14 & 0.579073 & 0.242681 & 0.920302 \\
\hline C15 & 0.548094 & 0.211785 & 0.924069 \\
\hline
\end{tabular}




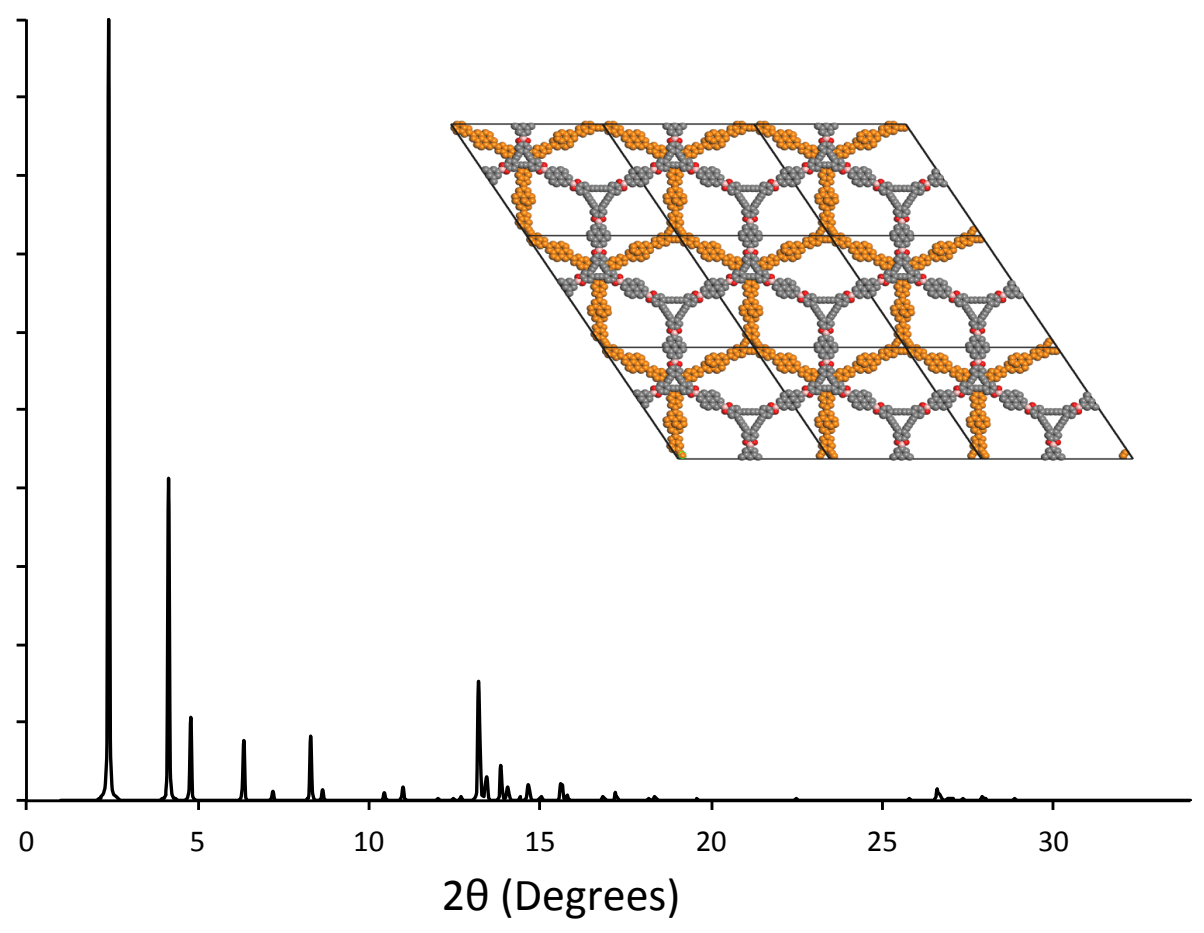

Figure S10. Simulated PXRD of Py-MV-DBA-COF modeled using a gra unit cell (top right). 


\section{F. TGA Profile}

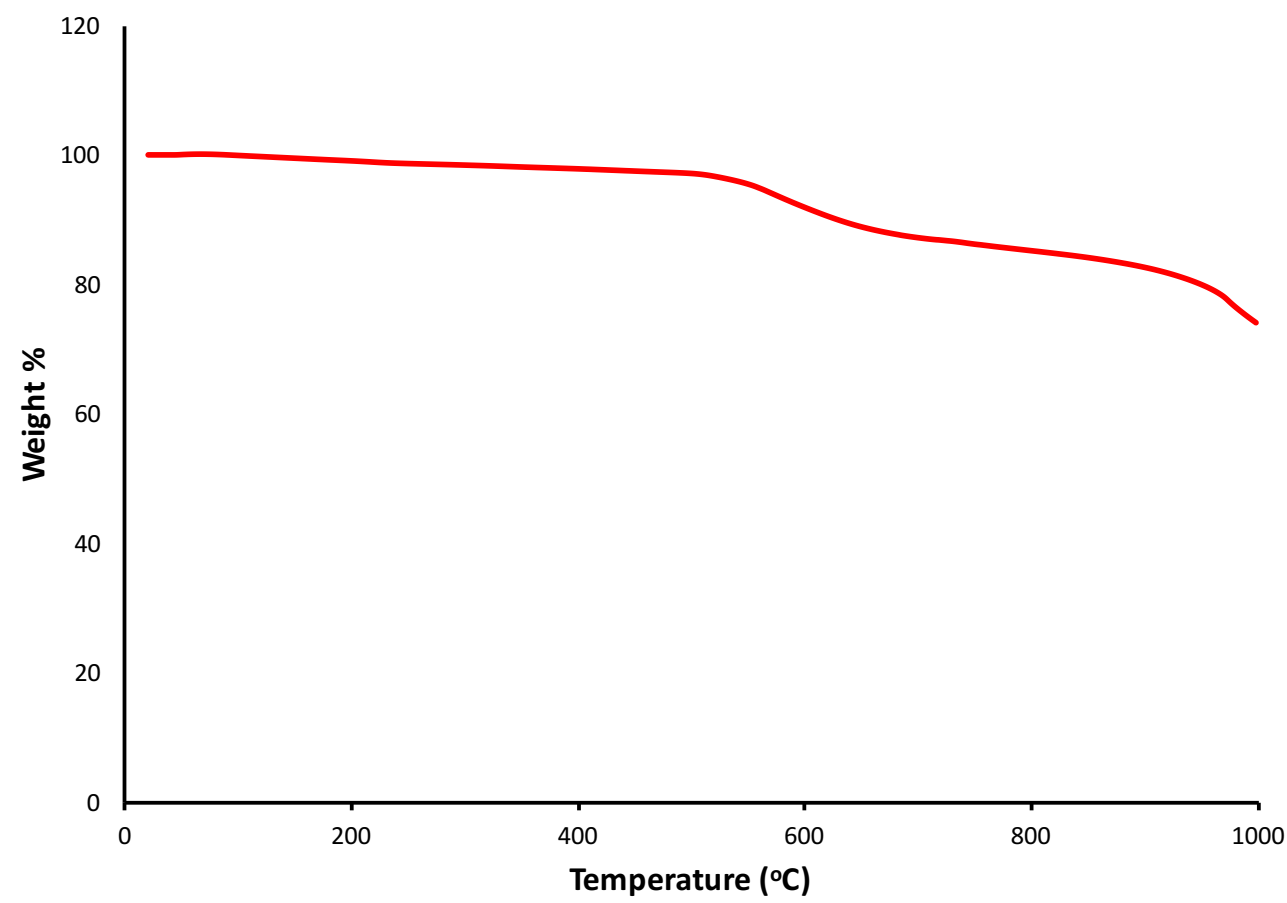

Figure S11. TGA plot for Py-DBA-COF 1.

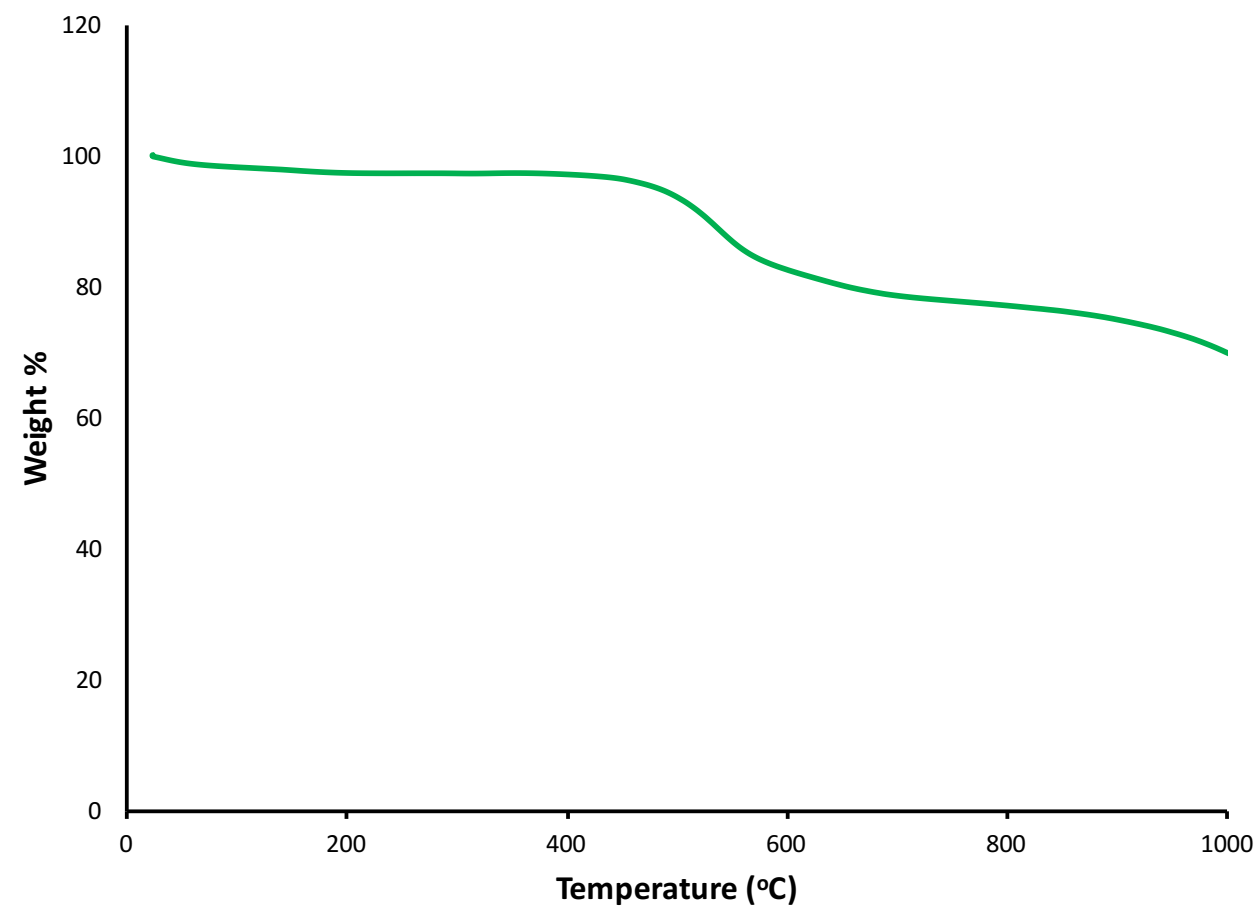

Figure S12. TGA plot for Py-DBA-COF 2. 


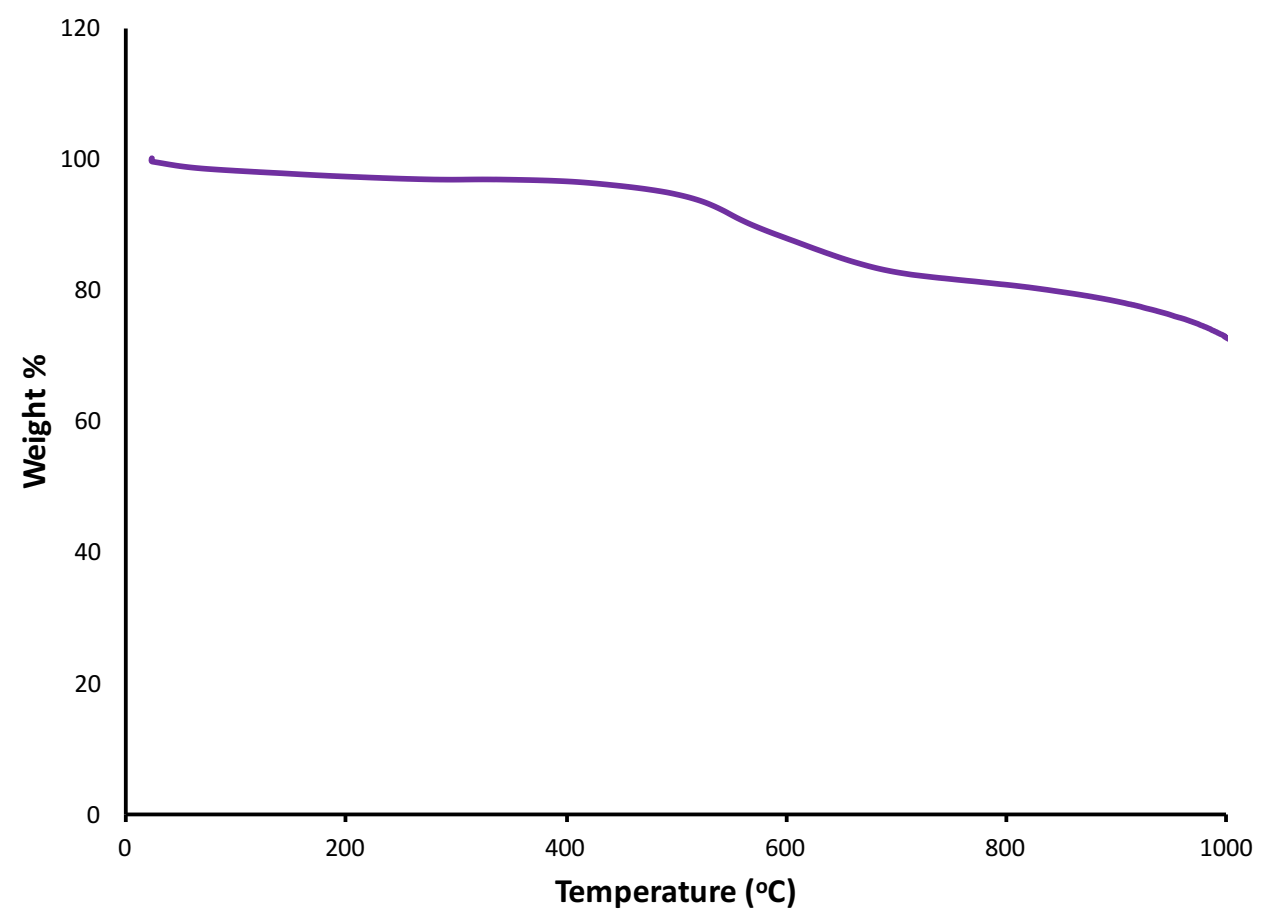

Figure S13. TGA plot for Py-MV-DBA-COF. 


\section{G. Surface Area Analysis}

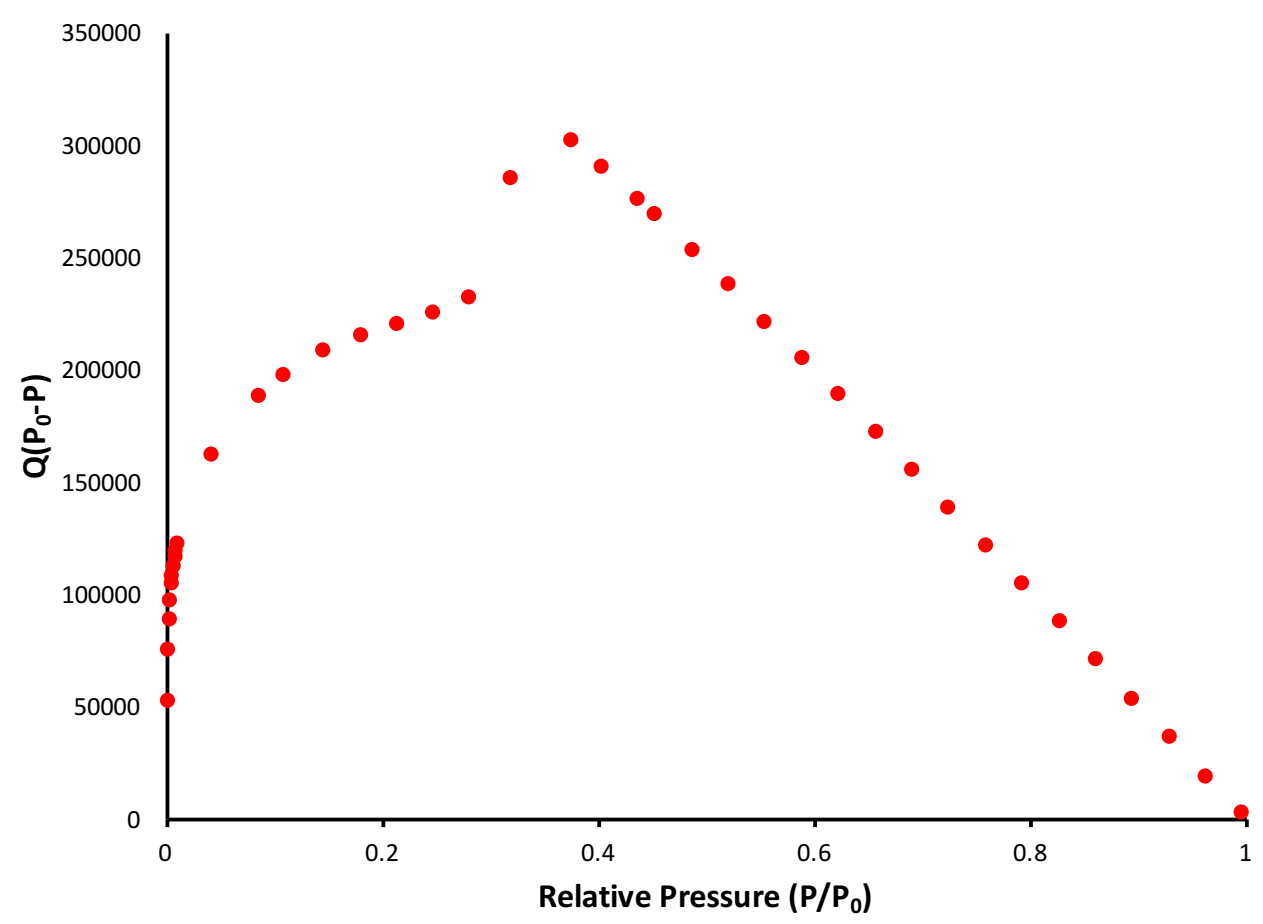

Figure S14. BET surface area analysis of Py-DBA-COF 1. 


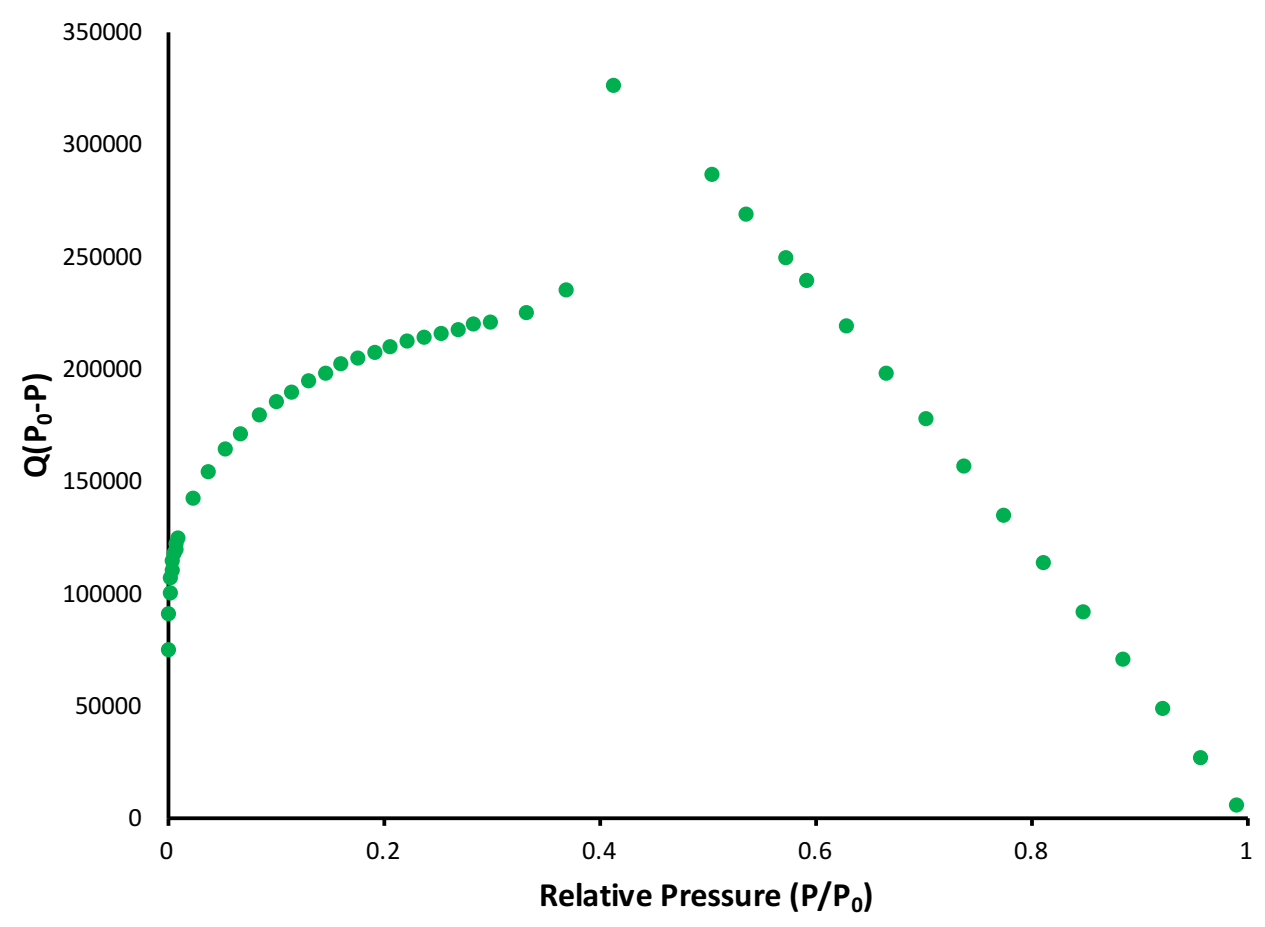

BET Surface Area
\begin{tabular}{|c|c|c|}
\hline $\mathbf{P} / \mathbf{P}_{\mathbf{o}}$ & $\mathbf{m}^{\mathbf{2}} \mathbf{g}^{-1}$ & $\mathbf{R}^{\mathbf{2}}$ \\
\hline $0.05-0.15$ & 1297.5 & 0.9997 \\
\hline $0.05-0.25$ & 1354.7 & 0.9997 \\
\hline $0.05-0.37$ & 1403.1 & 0.9988 \\
\hline
\end{tabular}

Figure S15. BET surface area analysis of Py-DBA-COF 2. 


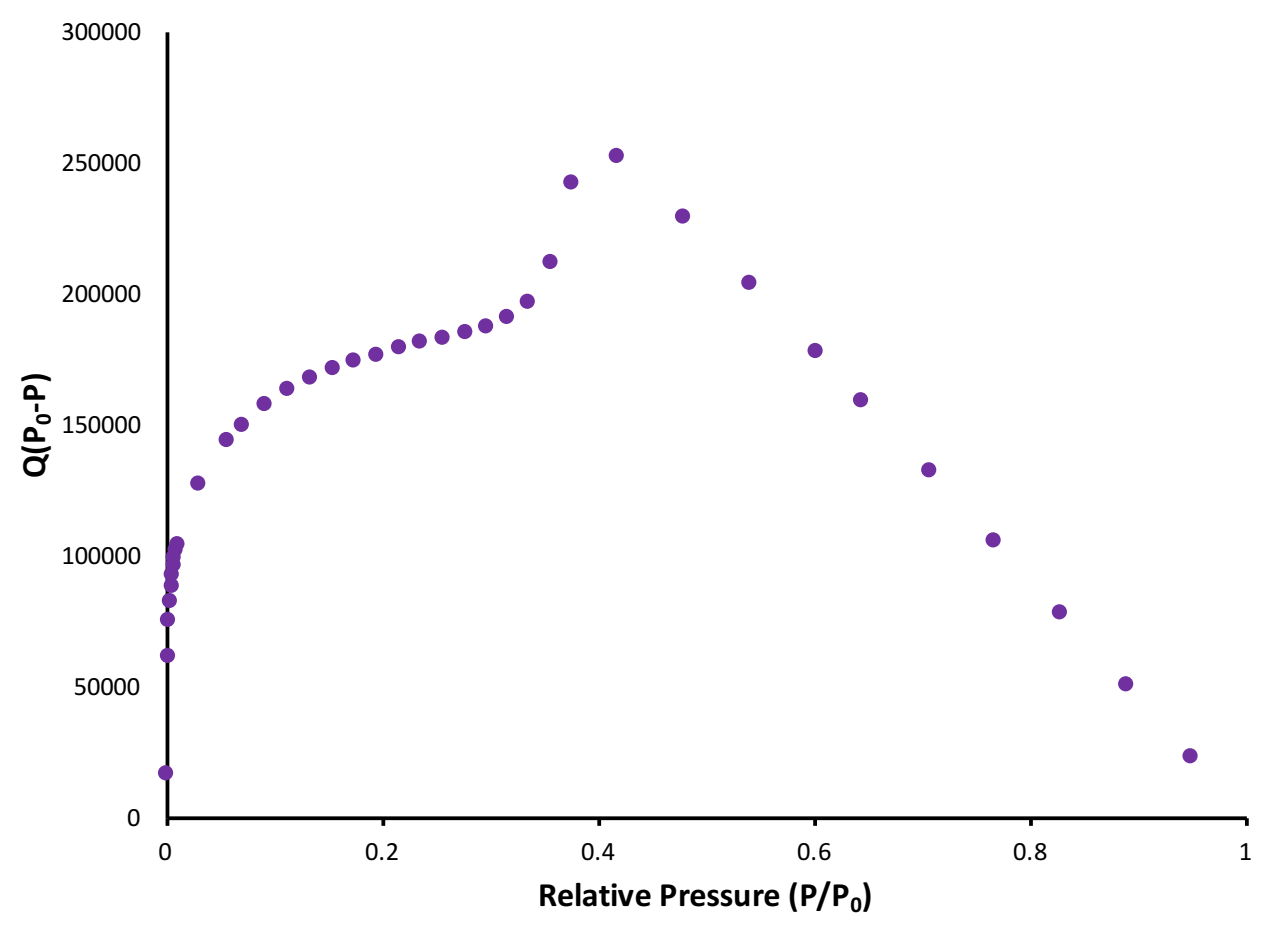

Figure S16. BET surface area analysis of Py-MV-DBA-COF. 


\section{H. Solid State ${ }^{13} \mathrm{C}$ NMR spectra}

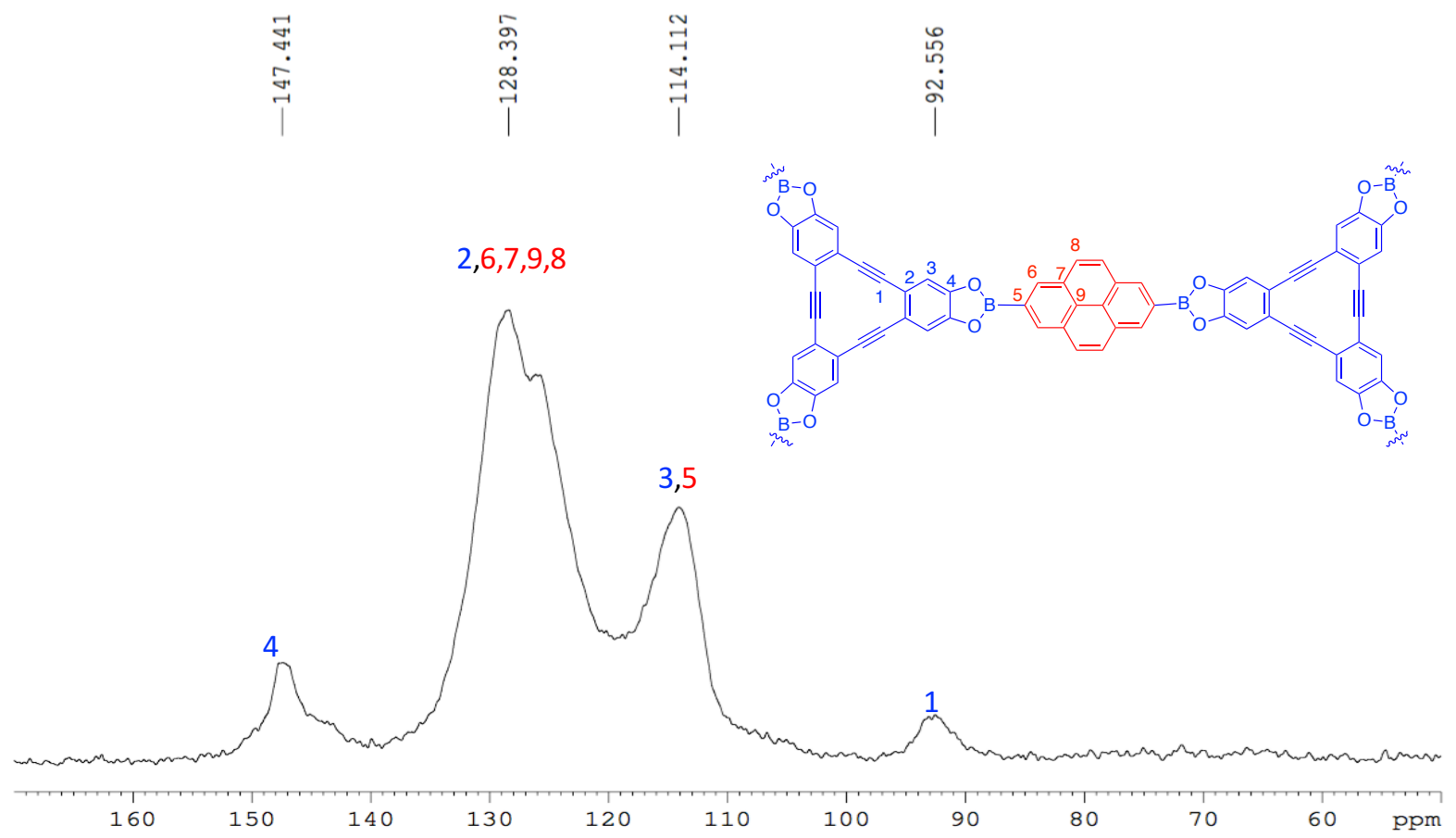

Figure S17. ${ }^{13} \mathrm{C}$ CP-MAS $75 \mathrm{MHz}$ solid-state NMR spectrum of Py-DBA-COF 1.

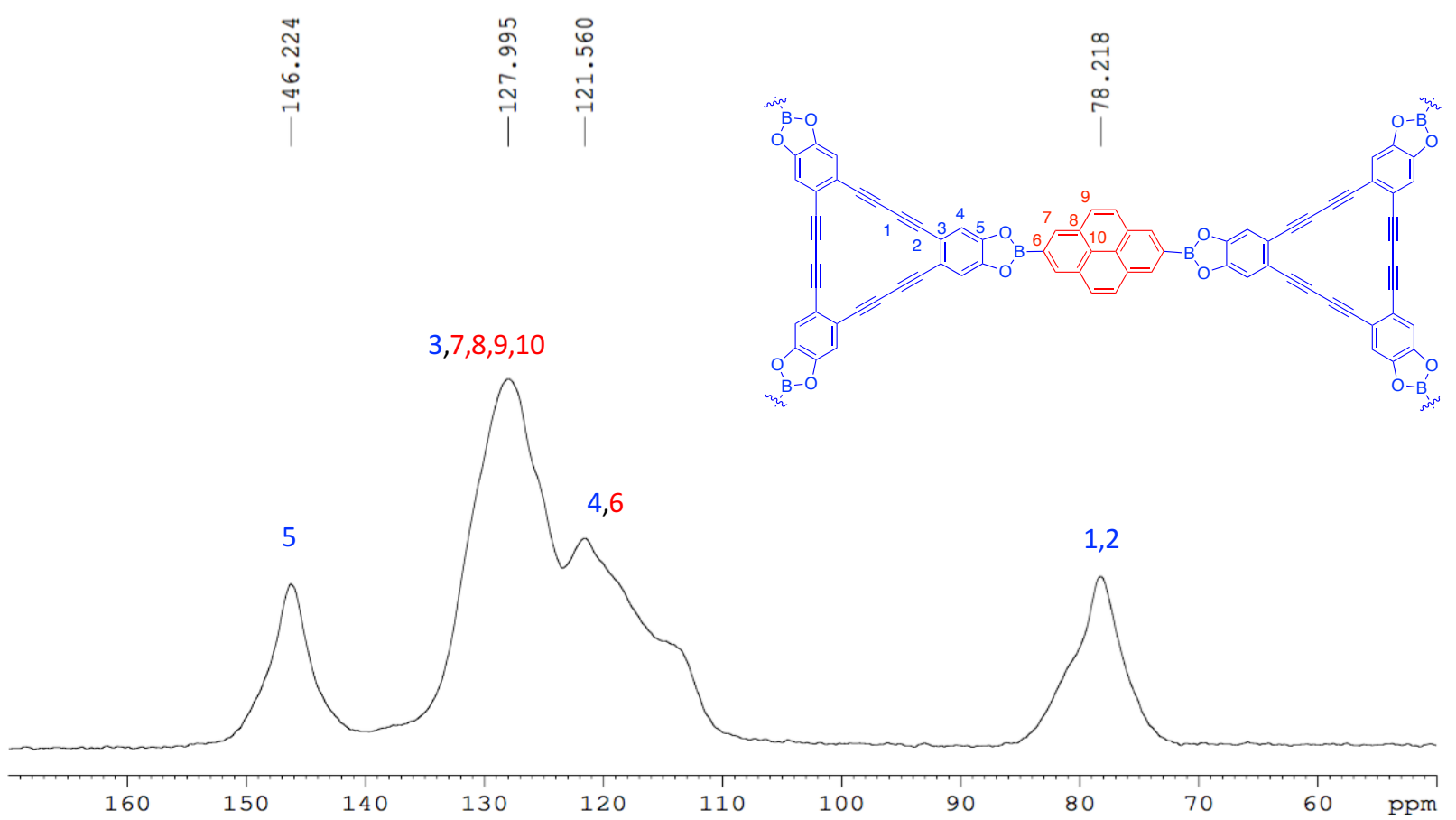

Figure S18. ${ }^{13} \mathrm{C}$ CP-MAS $75 \mathrm{MHz}$ solid-state NMR spectrum of Py-DBA-COF 2. 


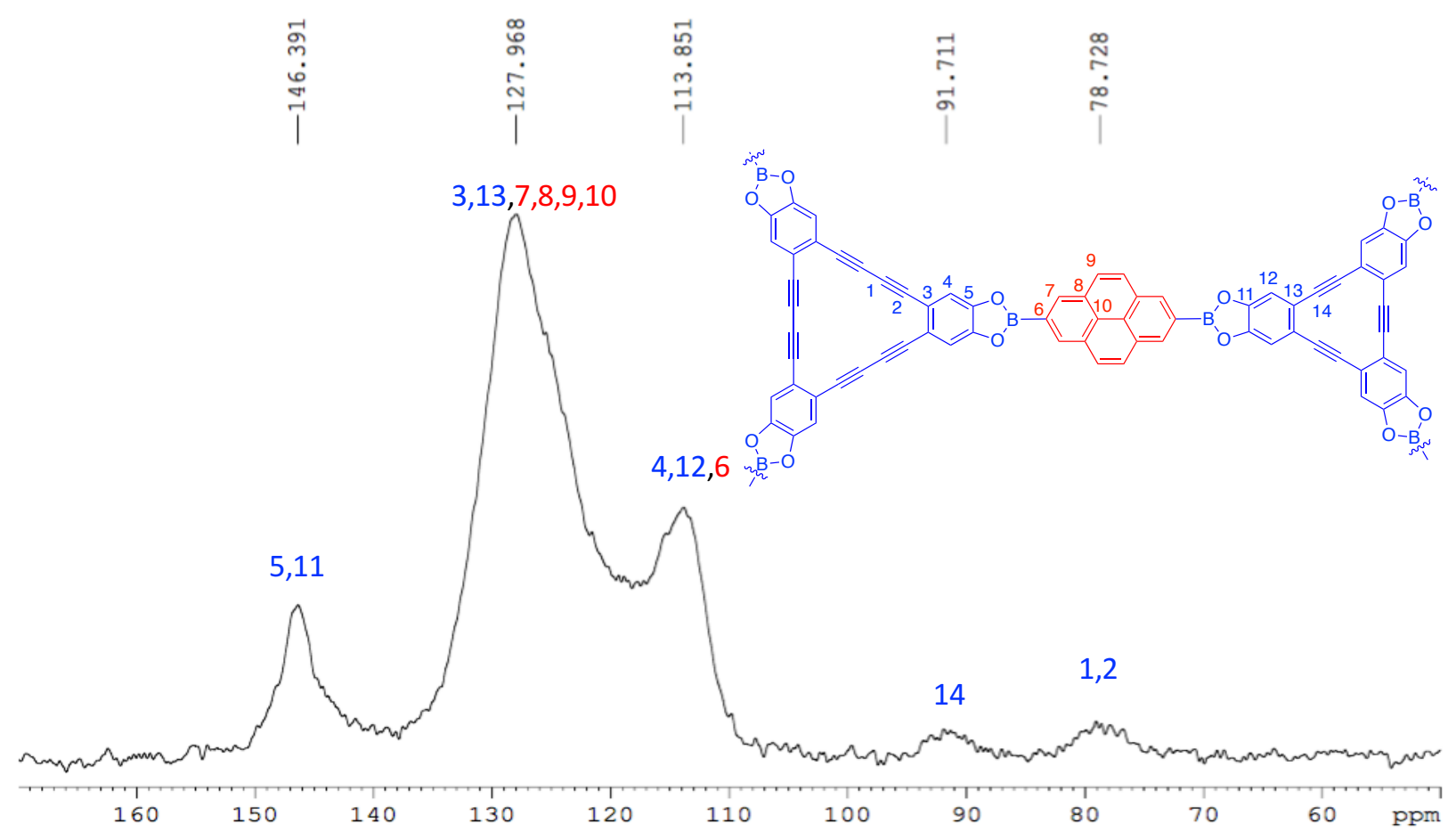

Figure S19. ${ }^{13} \mathrm{C}$ CP-MAS $75 \mathrm{MHz}$ solid-state NMR spectrum Py-MV-DBA-COF. 


\section{SEM images}
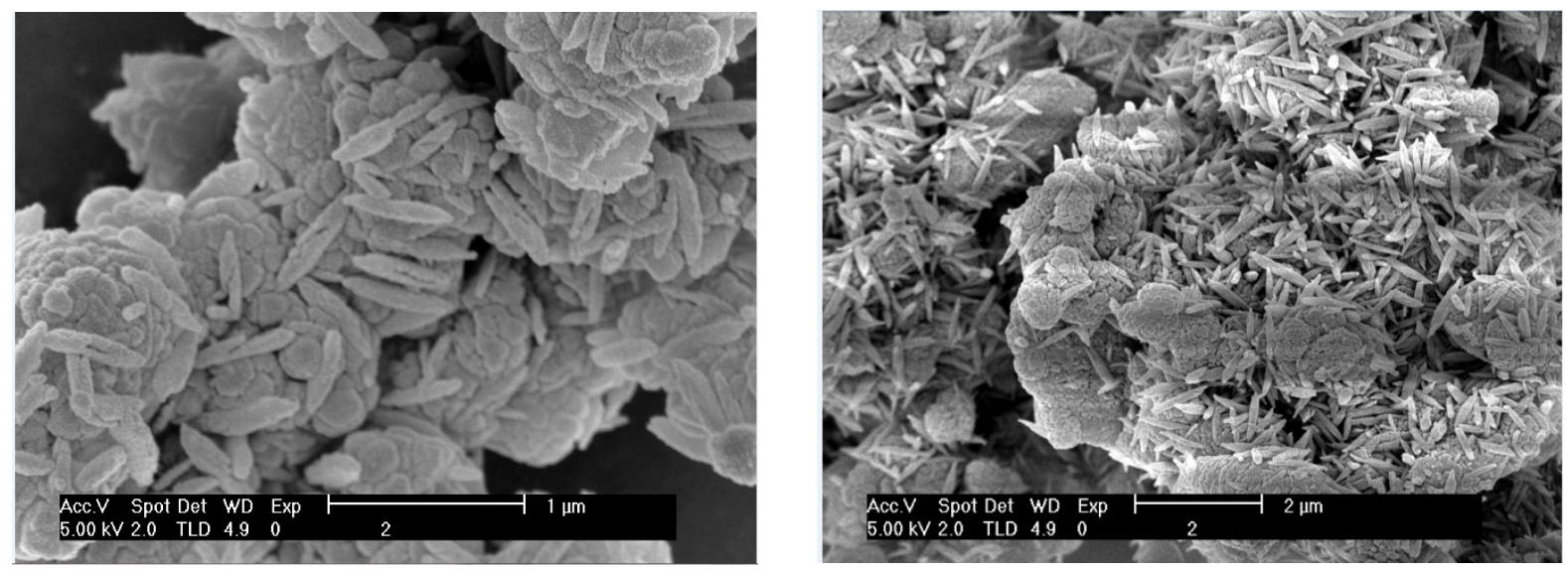

Figure S20. SEM images of Py-DBA-COF 1.
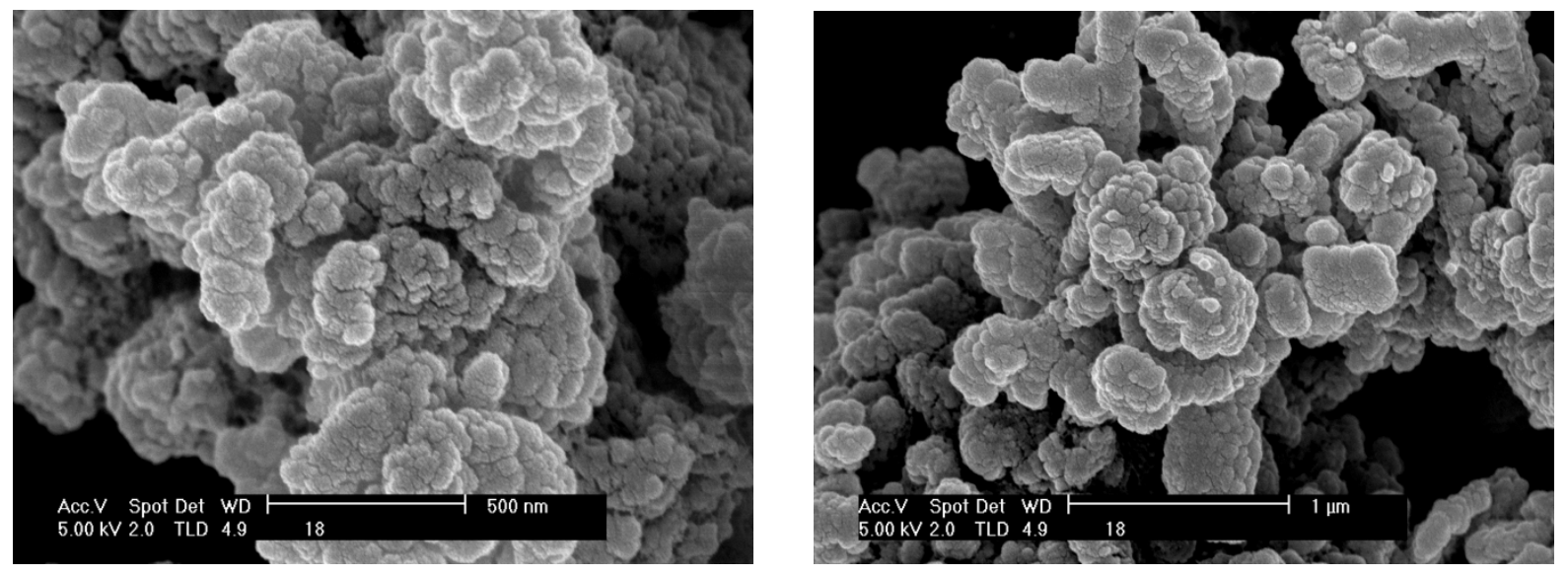

Figure S21. SEM images of Py-DBA-COF 2.
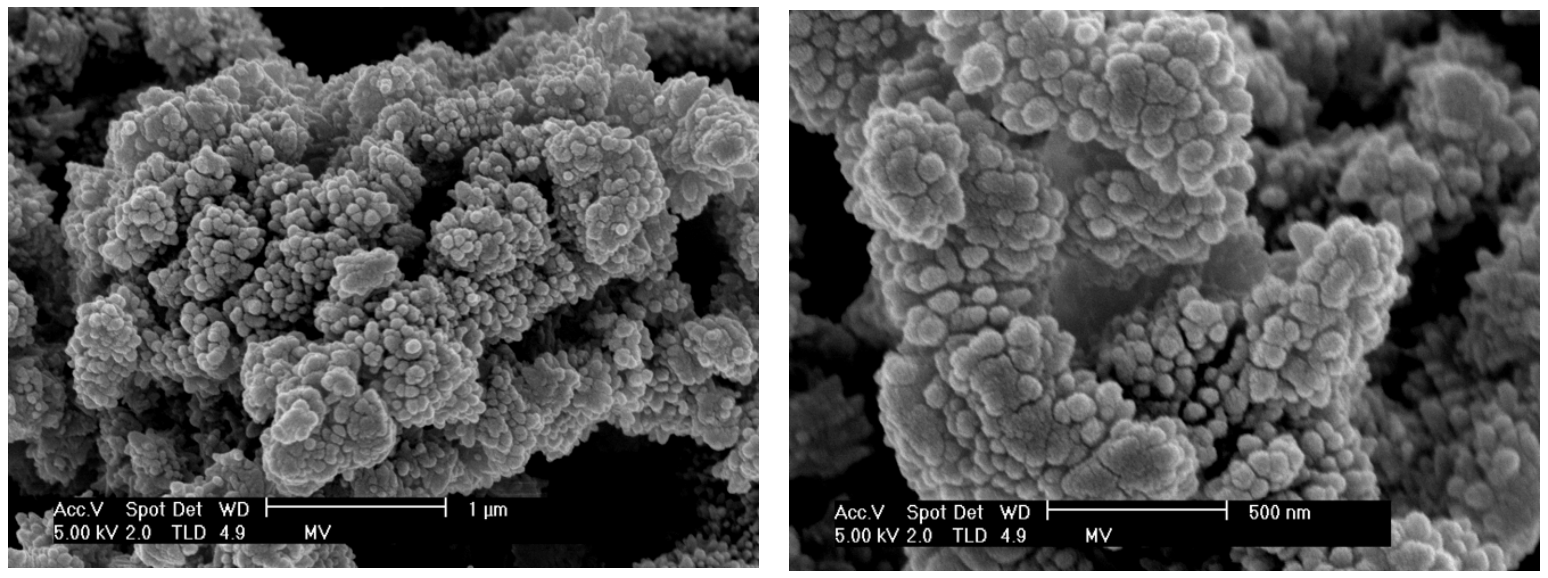

Figure S22. SEM images of Py-MV-DBA-COF. 


\section{J. UV-Vis and Fluorescence}

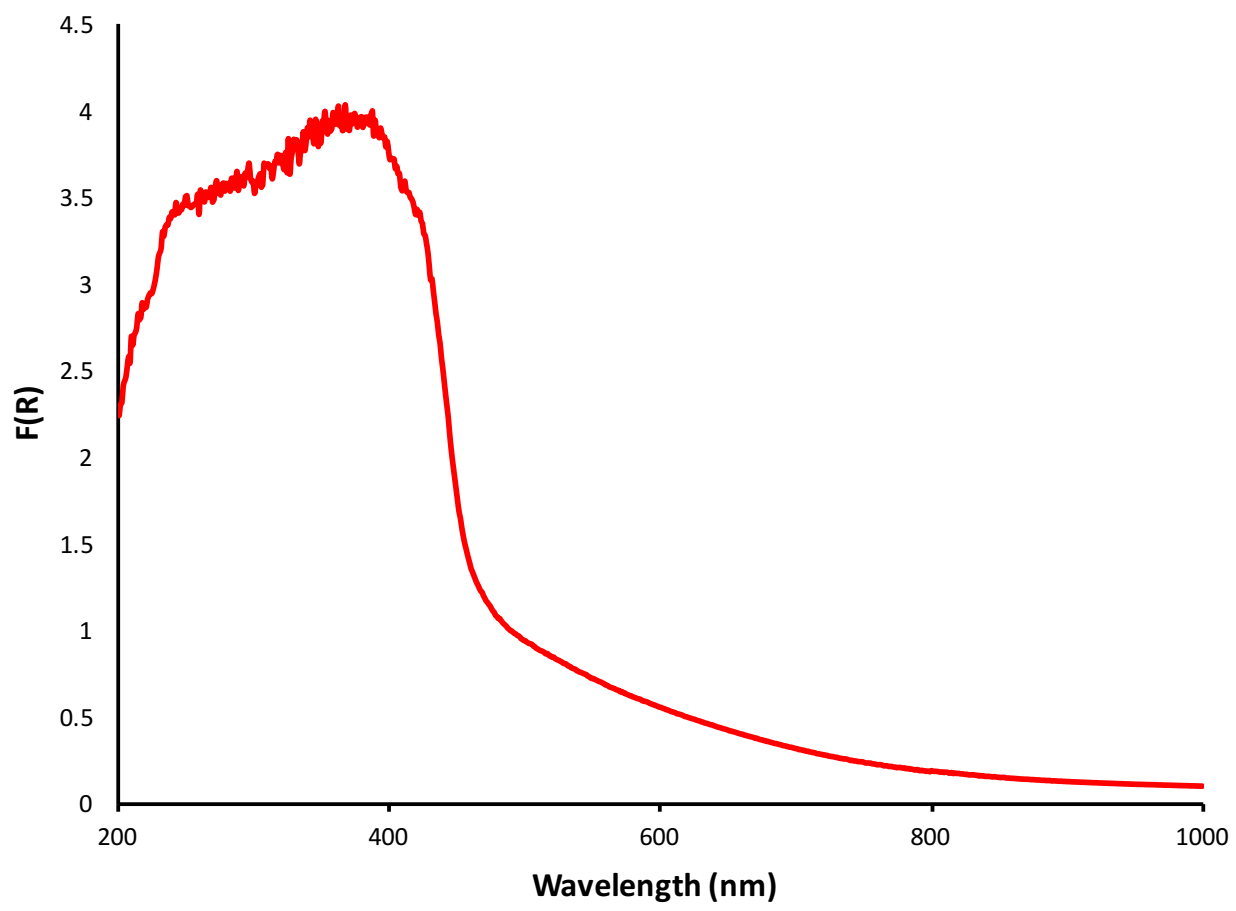

Figure S23. Kubelka-Munk function diffuse reflectance spectrum of Py-DBA-COF 1.

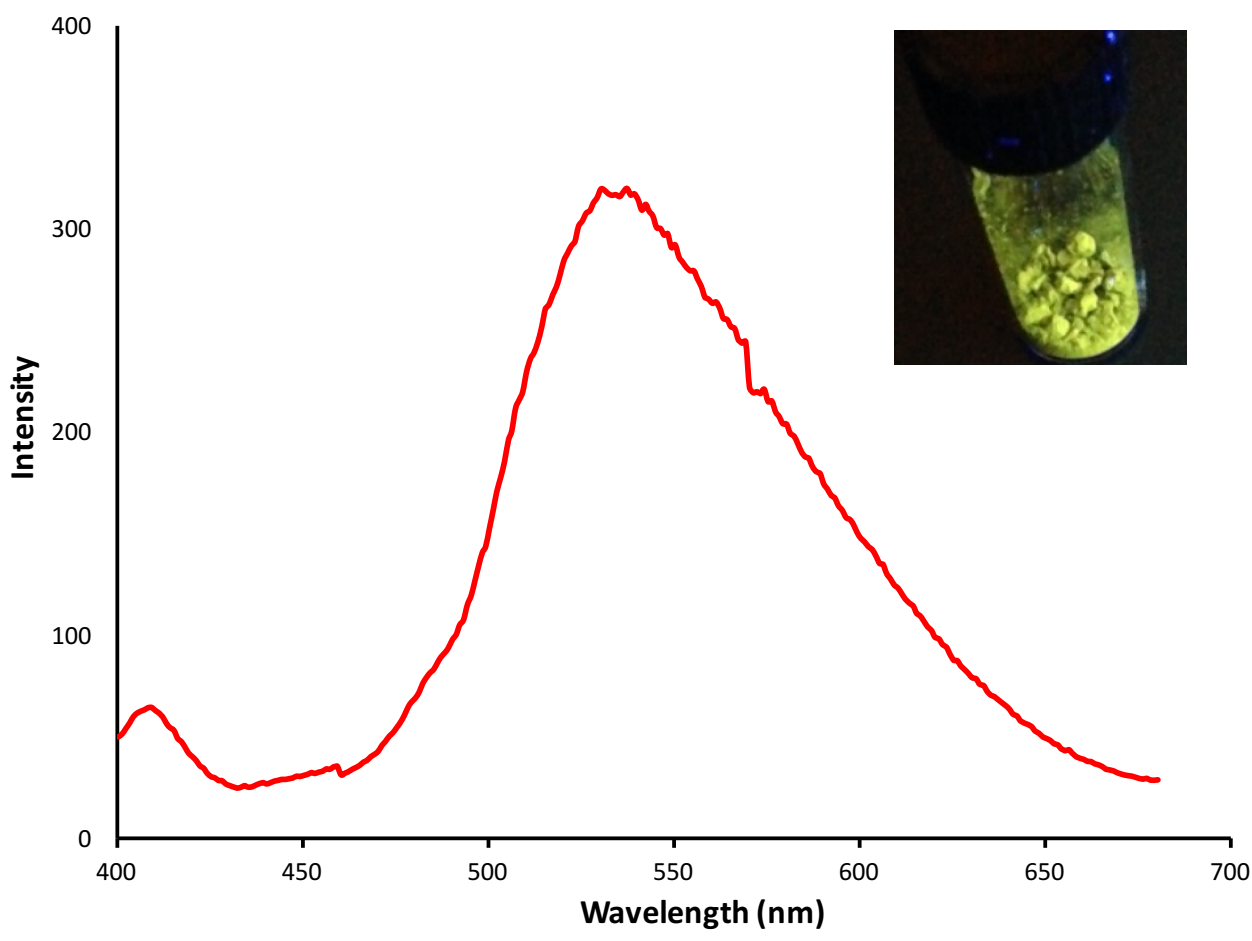

Figure S24. Py-DBA-COF 1 solid state emission spectrum $\left(\lambda_{\text {excitation }}=350 \mathrm{~nm}\right)$. 


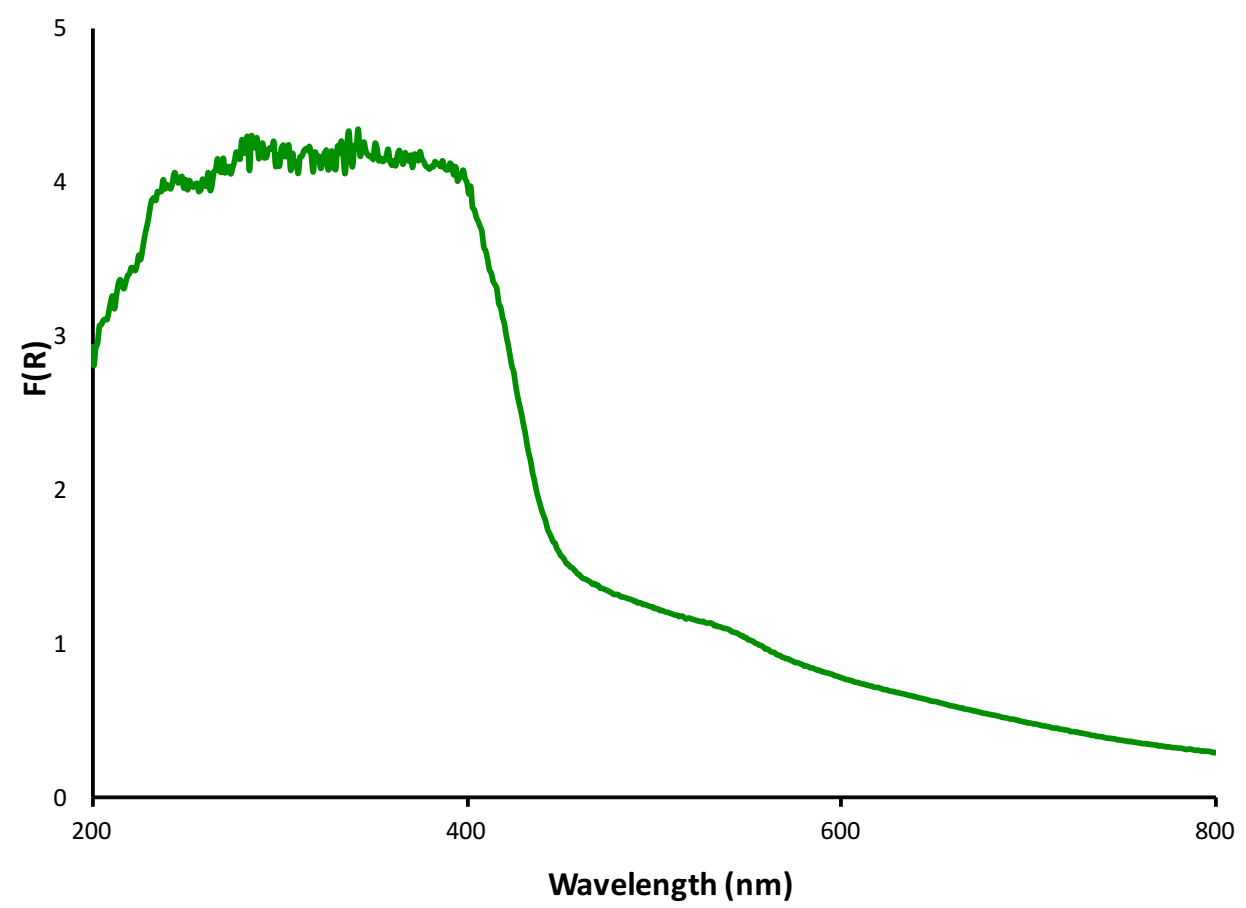

Figure S25. Kubelka-Munk function diffuse reflectance spectrum of Py-DBA-COF 2.

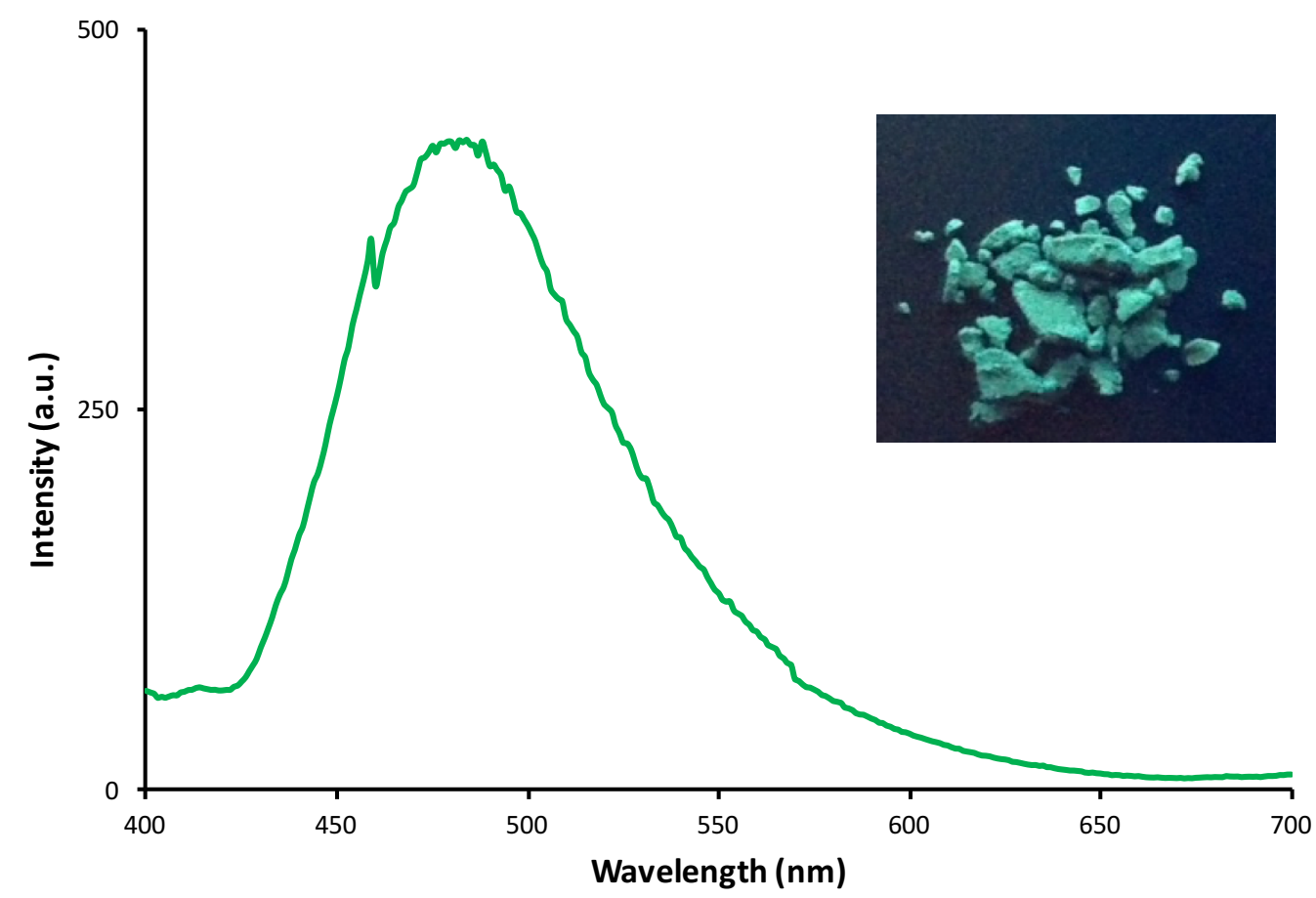

Figure S26. Py-DBA-COF 2 solid-state emission spectrum $\left(\lambda_{\text {excitation }}=365 \mathrm{~nm}\right)$. 


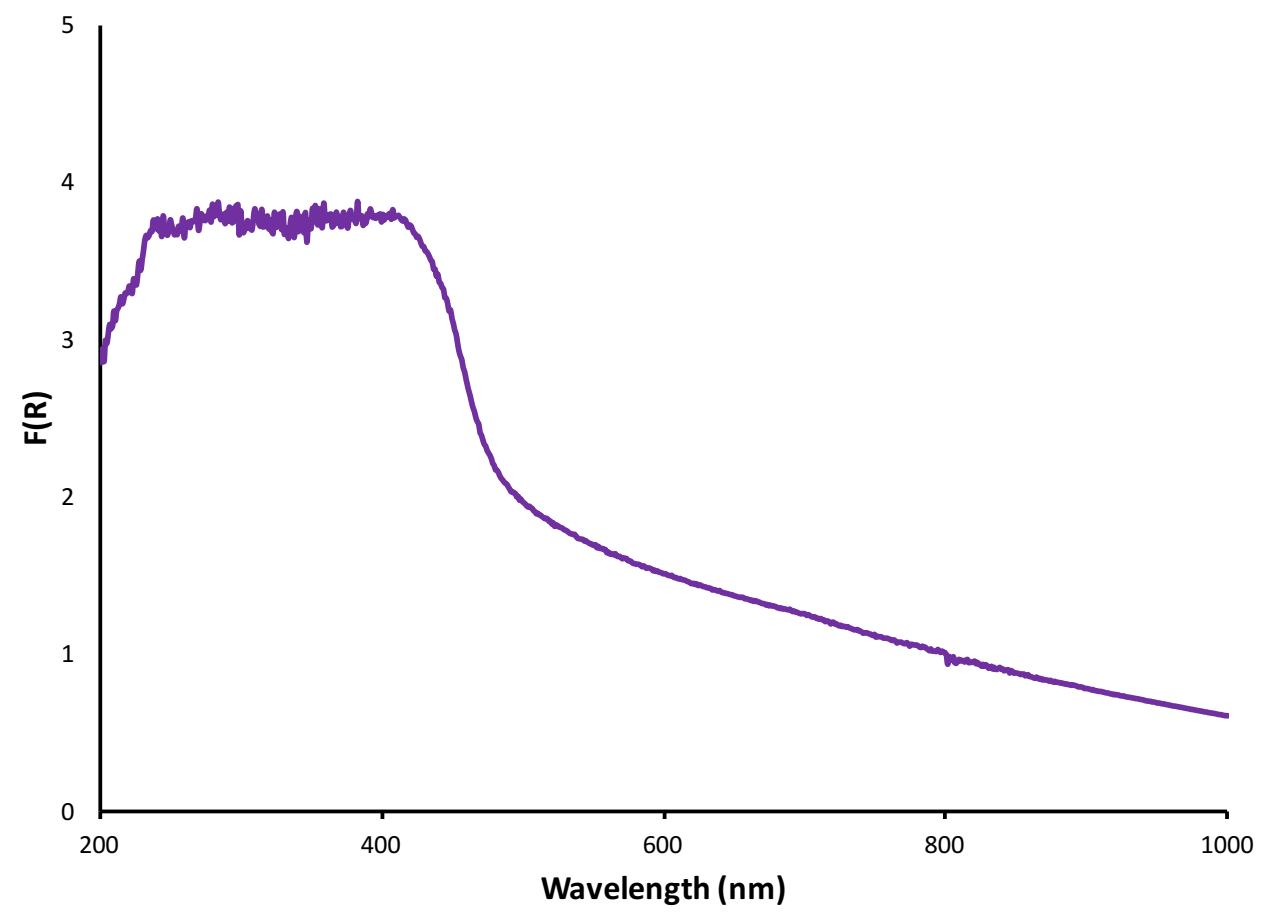

Figure S27. Kubelka-Munk function diffuse reflectance spectrum of Py-MV-DBA-COF.

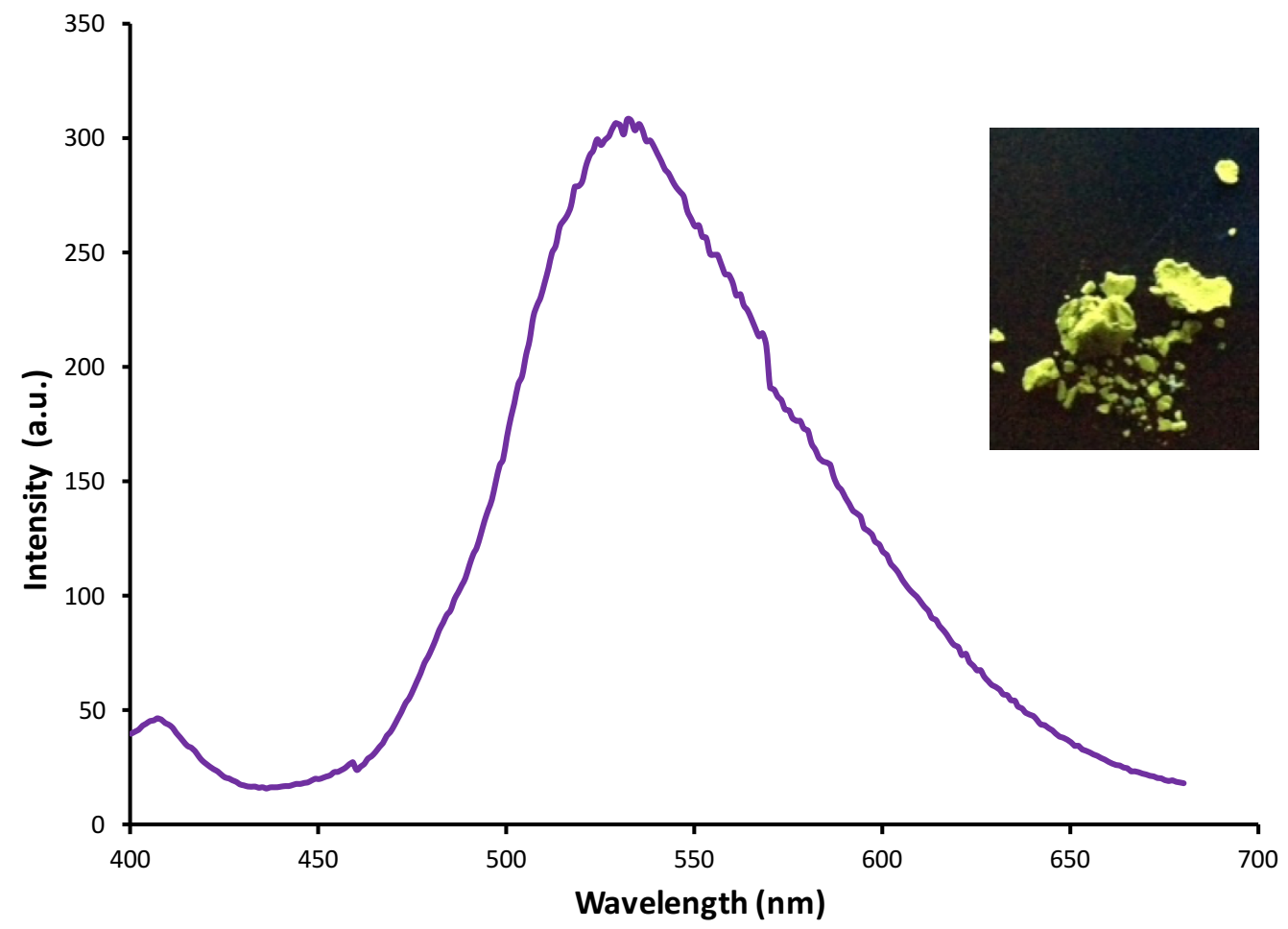

Figure S28. Py-MV-DBA-COF solid-state emission spectrum $\left(\lambda_{\text {excitation }}=350 \mathrm{~nm}\right)$. 


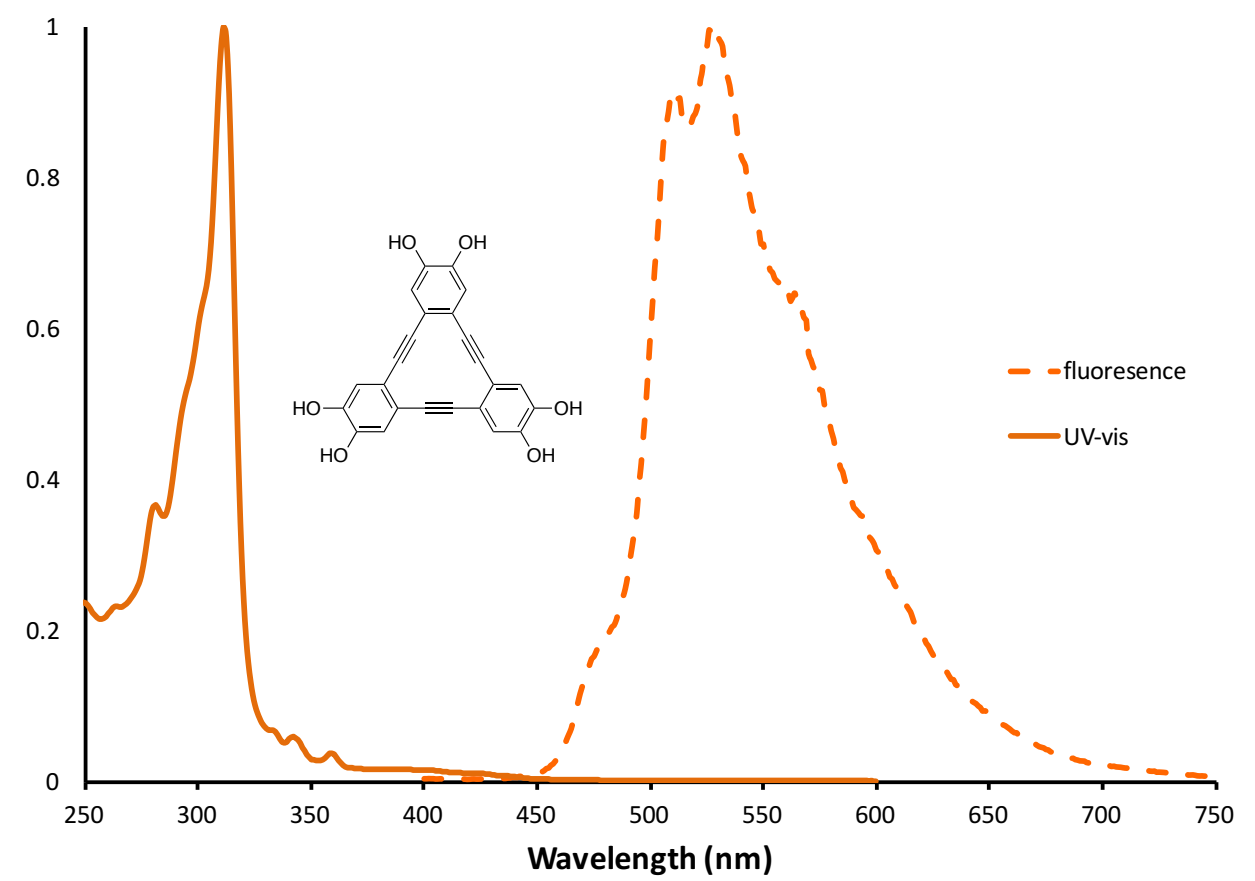

Figure S29. Normalized UV-vis (solid) and emission (dashed) spectra of DBA[12]-OH (6.88 x $10^{-6} \mathrm{M}, \lambda_{\text {excitation }}=311 \mathrm{~nm}$ ) in THF. *

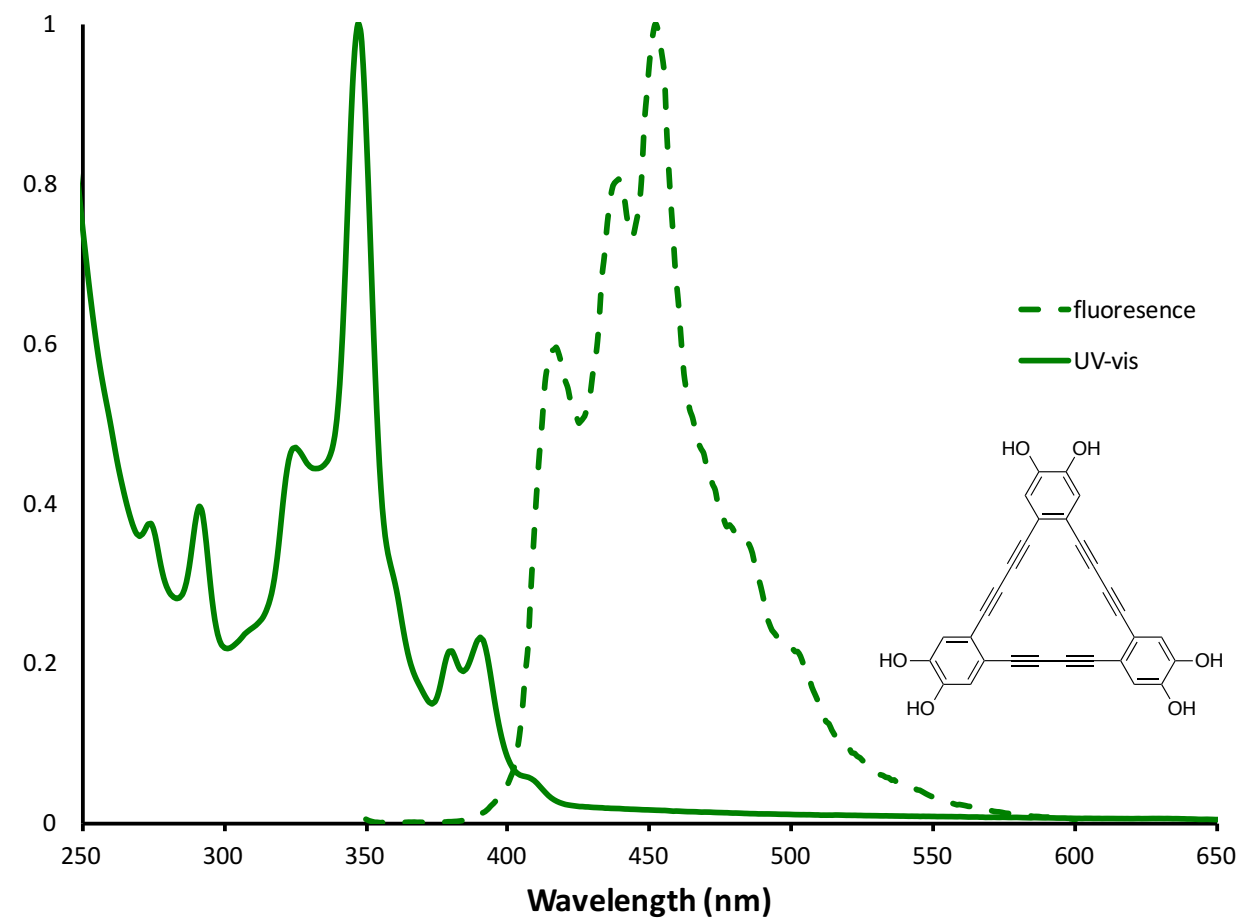

Figure S30. Normalized UV-vis (solid) and emission (dashed, $\lambda_{\text {excitation }}=347 \mathrm{~nm}$ ) spectra of DBA[18]-OH (3.65 x 10 $\left.0^{-6} \mathrm{M}\right)$ in THF. * 
* DBA[12]-based structures are known to have Stokes shifts that are larger than DBA[18]-based structures due to the symmetry selection rules for the forbidden transitions of each monomer. ${ }^{5}$ For instance, DBA[12]-OH exhibits intense absorption band at $311 \mathrm{~nm}$ (Figure S29), whereas DBA[18]-OH exhibits an intense absorption band at $347 \mathrm{~nm}$ (Figure S30). The former is due to the fact that the lowest-energy transition is symmetry forbidden, while the later is attributed to the extra ethynyl groups of $\mathrm{DBA}[18]-\mathrm{OH}$ which extends the $\pi$-conjugation. The absorption maxima for $\mathrm{DBA}[18]-\mathrm{OH}$ can be assigned to a forbidden transition $\left({ }^{1} A_{1}{ }^{\prime} \rightarrow{ }^{1} A_{2}{ }^{\prime}\right)$ that gains intensity on account of vibronic coupling in the excited state or thermal motion in the ground state. ${ }^{6}$ Since DBA[12] does not contain these extra ethynyl groups, the symmetry selection rules for the forbidden transitions dominate. This likely explains why DBA[12]-OH exhibits a weaker absorption band at longer wavelengths (340-450 nm). However, it is believed that the origin of the large Stokes shift for DBA[12]-based materials is linked to this weak absorption band.

\section{K. COF Hydrolysis ${ }^{1} \mathrm{H}$ NMR Spectra}

Hydrolysis ${ }^{1} \mathrm{H}$ NMR spectra were recorded by digesting ca. $3 \mathrm{mg}$ of COF powder in $1 \mathrm{~mL}$ of DMSO- $d_{6}$ and $50 \mu \mathrm{L} 1 \mathrm{M} \mathrm{HCl}$. The resulting suspension was allowed to sit for 5 minutes to allow for complete dissolution of the powder before the spectrum was recorded.

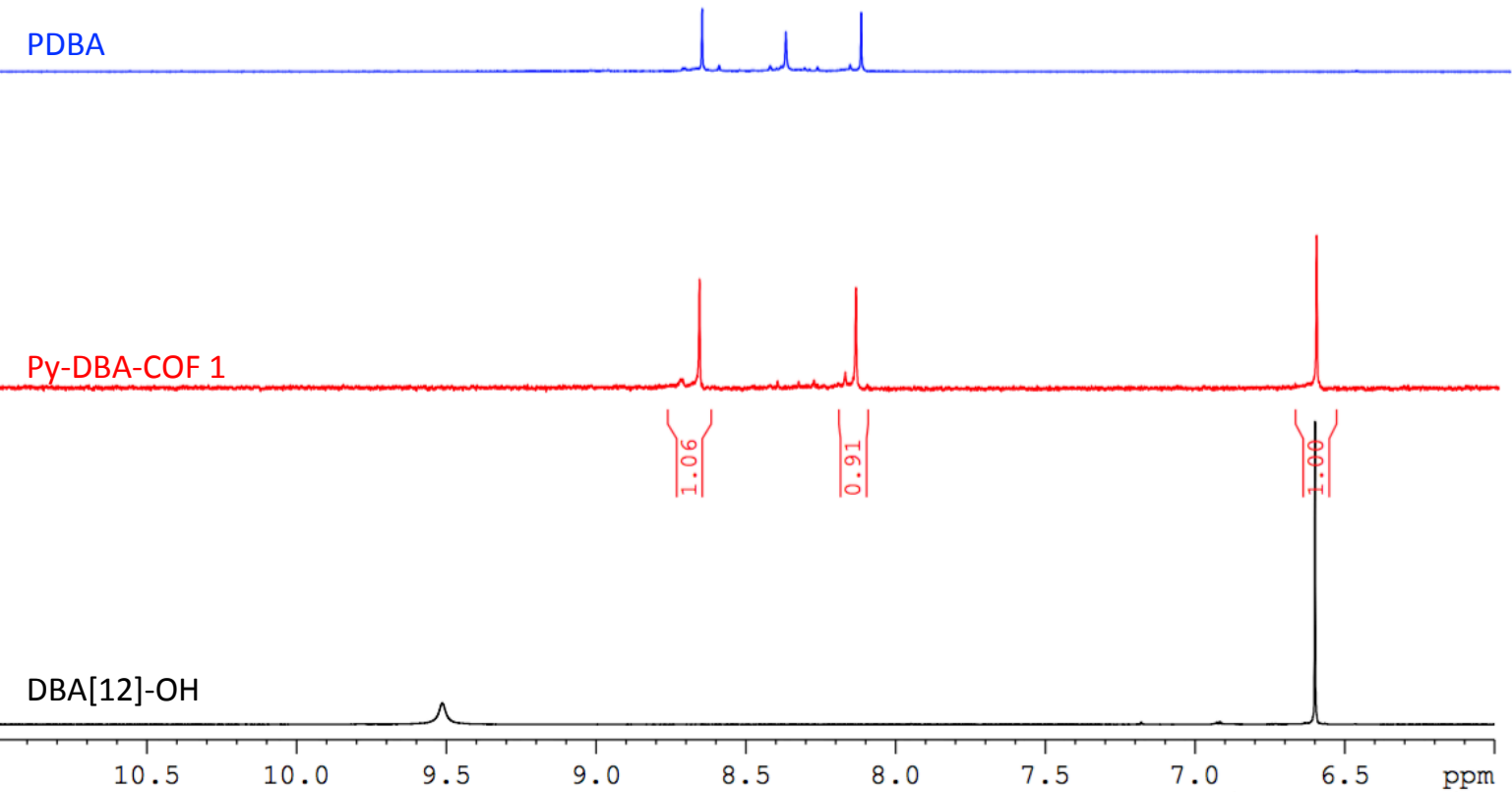

Figure S31. Stacked ${ }^{1} \mathrm{H}$ NMR spectra of PDBA (top, blue), Py-DBA-COF 1 (middle, red), and DBA[12]-OH (bottom, black) all in DMSO- $d_{6}$. 

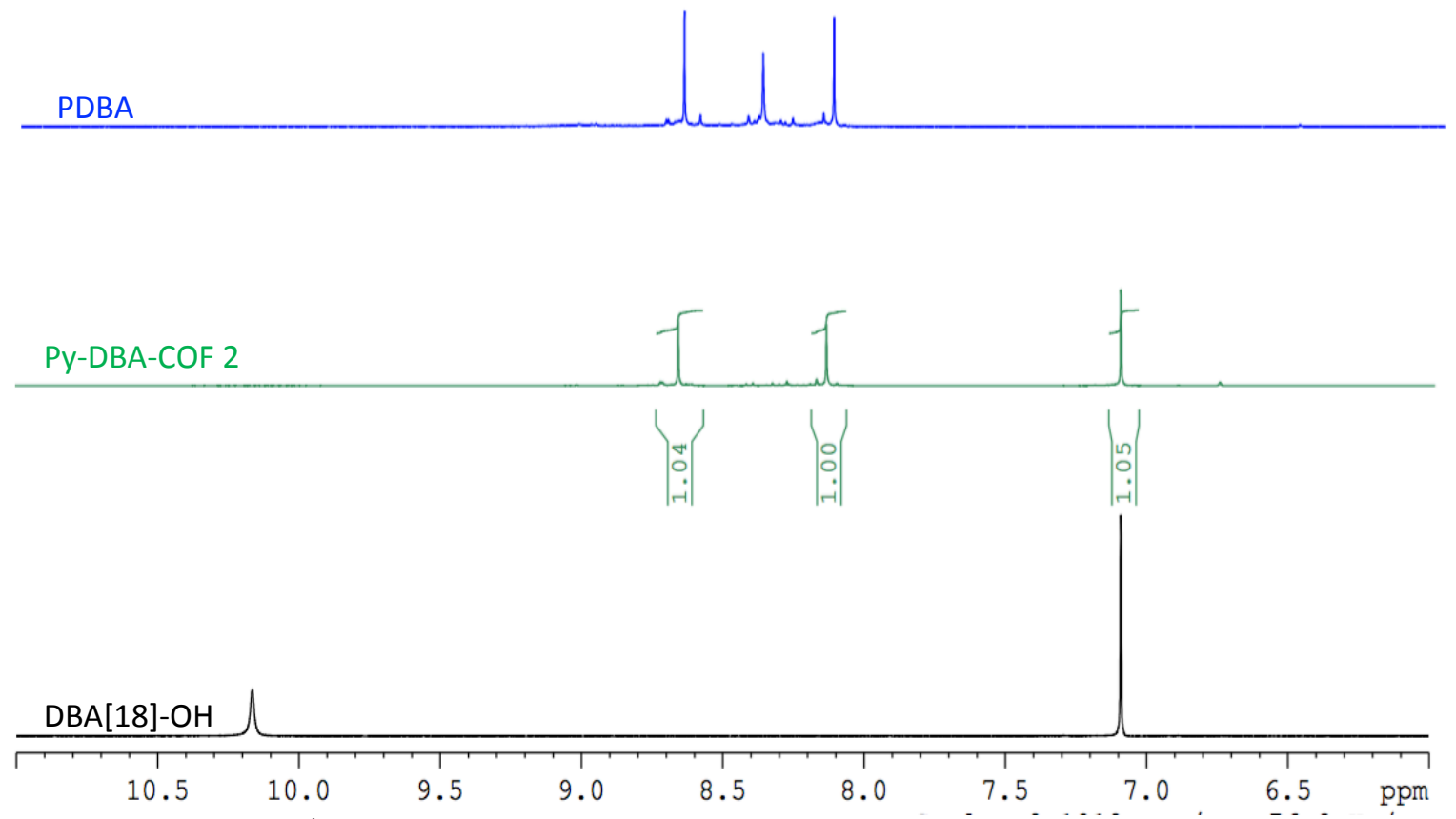

Figure S32. Stacked ${ }^{1} \mathrm{H}$ NMR spectra of PDBA (top, blue), Py-DBA-COF 2 (middle, green), and $\mathrm{DBA}[18]-\mathrm{OH}$ (bottom, black) all in DMSO- $d_{6}$. 

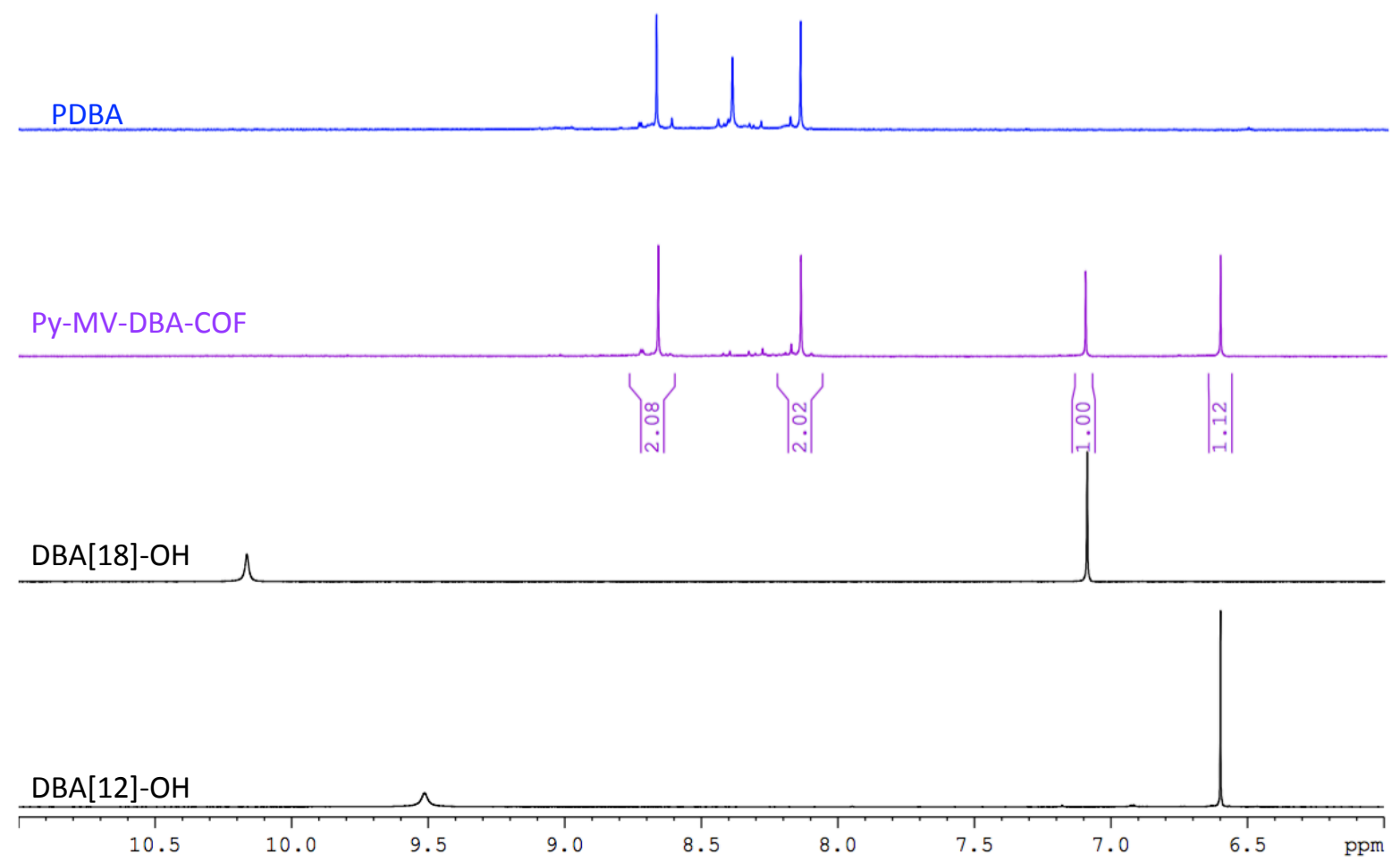

Figure S33. Stacked ${ }^{1} \mathrm{H}$ NMR spectra of PDBA (top, blue), Py-MV-DBA-COF (top middle, purple), DBA[18]-OH (bottom middle, black) and DBA[12]-OH (bottom, black) all in DMSO- $d_{6}$.

\section{References:}

[1] Wan, S.; Guo, J.; Kim, J.; Ihee, H.; Jiang, D. A Belt-Shaped, Blue Luminescent, and Semiconducting Covalent Organic Framework. Angew. Chem. Int. Ed. 2008, 47, 88268830 .

[2] Baldwin, L. A.; Crowe, J. W.; Shannon, M. D.; Jaroniec, C. P.; McGrier, P. L. 2D Covalent Organic Frameworks with Alternating Triangular and Hexagonal Pores. Chem. Mater. 2015, 27, 6169-6172.

[3] Côté, A. P.; Benin, A. I.; Ockwig, N. W.; O’Keeffee, M.; Matzger, A. J.; Taghi, O. M. Porous, Crystaliine, Covalent Organic Frameworks, Science 2005, 310, 1166-1170.

[4] Spitler, E. L.; Koo, B. T.; Novotney, J. L.; Colson, J. W.; Uribe-Romo, F. J.; Guitierrez, G. D.; Clancy, P.; Dichtel, W. R. A 2D Covalent Organic Framework with 4.7-nm Pores and Insight into Its Interlayer Stacking. J. Am. Chem. Soc. 2011, 133, 19416-19421.

[5] Kamada, K,; Antonov, L.; Yamada, S.; Ohta, K.; Yoshimura, T.; Tahara, K.; Inaba, A.; Sonoda, M.; Tobe, Y. Two-Photon Absorption Properties of Dehydrobenzo[12]annulenes 
and Hexakis(phenylethynyl)benzenes: Effect of Edge-Linkage. ChemPhysChem. 2007, 8, 2671-2677.

[6] Anand, S.; Varnavski, Ol.; Marsden, J. A.; Haley, M. M.; Schlegel, H. B.; Goodson, T. Optical Excitations in Carbon Architectures Based on Dodecadehydrotribenzo[18]annulene. J. Phys. Chem. A 2006, 110, 1305-1318. 